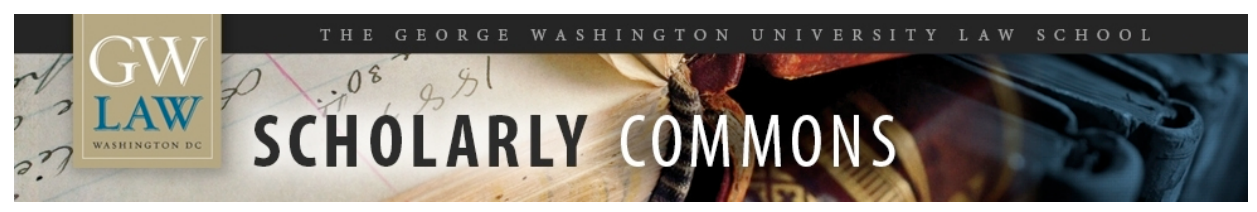

\title{
Property Rights and Property Rules for Commercializing Inventions
}

\author{
F. Scott Kieff \\ George Washington University Law School, skieff@law.gwu.edu
}

Follow this and additional works at: https://scholarship.law.gwu.edu/faculty_publications

Part of the Law Commons

\section{Recommended Citation}

F. Scott Kieff, Property Rights and Property Rules for Commercializing Inventions, 85 Minn. L. Rev. 697 (2001).

This Article is brought to you for free and open access by the Faculty Scholarship at Scholarly Commons. It has been accepted for inclusion in GW Law Faculty Publications \& Other Works by an authorized administrator of Scholarly Commons. For more information, please contact spagel@law.gwu.edu. 


\title{
Property Rights and Property Rules for Commercializing Inventions
}

\author{
F. Scott Kieff
}

I. Problems with Reward Alternatives to Patents ........... 705

A. Commercialization................................................ 707

B. Screening ............................................................ 712

II. Patents for Commercialization Without Underuse ...... 717

A. Property Rights to Avoid Underuse......................... 717

B. Price Discrimination to Avoid Dead-Weight Loss.... 727

C. Property Rules to Avoid Underuse ............................. 732

III. Commercialization by Design....................................... 736

IV. Commercialization and the Modern

Patent System

V. Commercialization and the Modern

Trademark System.

\section{INTRODUCTION}

The foundation for the American patent system is purely economic. The entire system stems from a constitutional grant of power to Congress to promote the useful arts, not to protect a constitutional right. ${ }^{1}$ Although rights-based theories do influence debates about intellectual property theory in general, the

$\dagger$ Visiting Assistant Professor, Northwestern University School of Law and Counsel to Jenner \& Block. This work was supported by funding from Jenner \& Block and prior drafts of this Article were presented to faculty workshops at the law schools of Northwestern University and George Mason University. I gratefully acknowledge the many questions and comments from workshop participants as well as the numerous discussions about earlier drafts with Michael Abramowicz, John Barton, Emil Dabora, Ken Dam, Manya Deehr, Rochelle Dreyfuss, John Duffy, Clint Francis, Paul Goldstein, Bob Gorman, David Haddock, Heather Hoecke, Chet Kamin, Leo Katz, Orin Kerr, Elliott Kieff, Jacqueline Kieff, Ed Kitch, Bruce Kobayashi, Eric Laumann, Jim Lindgren, Fred McChesney, Rob Merges, Katherine A. Moerke, Pauline Newman, Ralph Oman, Mike Rosow, Tom Pasternak, Giles Rich, Lisa Schneider, Steven Shavell, Henry Smith, and John Witherspoon. Please send correspondence to fskieff.91@alum.mit.edu (permanent address).

1. See U.S. ConST. art. I, § 8, cl. 8. 
consensus among those studying the American patent system is to focus on utilitarian approaches. ${ }^{2}$

Similarly, the primary impact of the American patent system is economic as well. Although evidenced by infringement

2. The rights-based theories are deontological, protection-based theories, often called "natural law" theories. The utilitarian theories are consequentialist, promotion-based theories, often called various "incentive" theories. One reason for the persistence of both sets of theories, at least in the American context, is the Constitution itself, which grants Congress the power to "promote the Progress of Science and Useful Arts, by securing for limited Times to Authors and Inventors the exclusive Right to their respective Writings and Discoveries." Id. On the one hand, the clause does at least contain the concept of securing or protecting. Indeed, this clause is the only clause in the entire unamended Constitution that contains the word "right." From time to time, some have unsuccessfully argued that the mandate is to protect a fundamental constitutional right. On the other hand, in this so-called Patent and Copyright Clause, the central and operative verb is "promote," and for trademarks, the constitutional source of Congressional power is the Commerce Clause. See U.S. CONST. art. I, $\S 8$, cl. 3. Whereas the rights-based views do exert some influence, American intellectual property law is dominantly shaped by utilitarian views, with a debate remaining over which utilitarian view should prevail. Although this Article refers only to the debate among utilitarian views, there is equal debate among the various protection-based views. Both sides of that debate agree that the patent right is a natural right, but they disagree about whether it belongs to the inventor or to society as a whole. In keeping with the teachings of Locke, some argue that by mixing one's labor with an invention, one owns the invention as a just reward. See JOHN LOCKE, The Second Treatise of Government, in TwO TREATISES OF GOVERNMENT 30320 (Peter Laslett ed., Cambridge Univ. Press 1960) (1690) (setting forth Locke's "just desserts" or "labor" theory). In keeping with the teachings of Hegel, others argue that inventions are so imbued with the labor and personhood of the inventor that they fundamentally belong to the individual inventor in much the same way that freedom and personal space are considered fundamental rights. See, e.g., MARGARET JANE RADIN, REINTERPRETING PROPERTY 44-48 (1993) (discussing Hegel's "personhood" theory). Yet those natural rights theories tying invention to inventor leave many questions unanswered. Assuming inventions are the natural property of the inventor, what rights do simultaneous inventors have? Should independent origination be a complete defense to patent infringement as it is for copyright infringement? More fundamentally, should the patent right include some affirmative right to use? Alternatively, some natural rights theories tie inventions to society. In keeping with the teachings of Thomas Jefferson, some argue that because one's use of knowledge does not interfere with the use by another, knowledge must be a fundamental right of society. See Letter from Thomas Jefferson to Isaac McPherson (Aug. 13, 1813), reprinted in JEFFERSON WRITINGS 1291-92 (Merrill D. Peterson ed., Library of America 1984) [hereinafter Letter from Thomas Jefferson] ("He who receives an idea from me, receives instruction himself without lessening mine; as he who lights his taper at mine, receives light without darkening me."). See generally DONALD S. Chisum, Craig Allen Nard, Herbert F. Schwartz, Pauline Newman \& F. SCOTT KIEFF, PRINCIPLES OF PATENT LAW 1-50 (1998) (reviewing the history and philosophy of patent law and collecting sources). 
verdicts reaching well into the hundreds of millions of dollars, ${ }^{3}$ the importance of the patent system cannot be measured merely in individual gains and losses. Economic research has shown that the national patent system has an important impact on long term international economic competitiveness and that patent law can function as a public policy tool for promoting national economic growth. ${ }^{4}$

3. See, e.g., Litton Sys., Inc. v. Honeywell, Inc., 87 F.3d 1559, 1566 (Fed. Cir. 1996) (describing the $\$ 1.2$ billion jury verdict), vacated, 520 U.S. 1111 (1997); Polaroid Corp. v. Eastman Kodak Co., No. 76-1634-MA, 1991 WL 4087, at *5 (D. Mass. Jan. 11, 1991) (awarding approximately $\$ 900$ million in lost profits, royalties, and interest).

4. See, e.g., Symposium on Patents and Technology Licensing, 21 RAND J. ECON. 103 (1990) (discussing the use of patent law as a tool to promote innovation and national economic development). Economic research over the past sixty years has amply established a causal link between the development of intellectual property and the growth of our national economy, while also showing that intellectual property is an increasingly critical component of United States capital and foreign trade. See generally NATIONAL BUREAU OF ECONOMIC RESEARCH, R \& D, PATENTS, AND PRODUCTIVITY (Zvi Griliches ed., 1984) (describing invention and technological change as major forces of growth in national economies and studying their connection to patents); Richard C. Levin et al., Appropriating the Returns from Industrial Research and Development, 1987 BROOKINGS PAPERS ON ECON. ACTIVITY 783 (1987) (discussing patents as tools for appropriating returns to investments in making and commercializing inventions); Edwin Mansfield, Patents and Innovation: An Empirical Study, 32 MGMT. SCI. 173 (1986) (describing the empirical evidence for the link between patents and innovation); Edwin Mansfield, Unauthorized Use of Intellectual Property: Effects on Investment, Technology Transfer, and Innovation, in GLOBAL DimENSIONS OF INTELLECTUAL PROPERTY RIGHTS IN SCIENCE AND TECHNOLOGY 107 (Mitchell B. Wallerstein et al. eds., 1993) (describing the impact of intellectual property rights and their enforcement on the processes of invention commercialization); Robert P. Merges, Uncertainty and the Standard of Patentability, 7 HIGH TECH. L.J. 1, 10-12 (1992) (discussing the impact of patents on firms' research and development investment decisions). Much of this work is based on the literature that explores the general importance of innovation to the growth of national economies. See, e.g., SIMON S. KUZNETS, SECUlaR MOVEMENTS IN PRODUCTION AND PRICES 1-58 (1930) (economic research showing a causal link between invention and technical change and the growth of national economies); JOSEPH A. SCHUMPETER, 1 BUSINESS CYCLES 84-102 (1939) (same) [hereinafter SCHUMPETER, BUSINESS CYCLES]; Robert K. Merton, Fluctuations in the Rate of Industrial Invention, 49 Q.J. ECON. 454, 464 (1935) (same); GEOFFREY WYATT, THE ECONOMICS OF INVENTION 147-231 (1986) (reviewing the field of economic literature on the connection between invention and technical change and the growth of national economies); Zvi Griliches, Productivity, R\&D, and Basic Research at the Firm Level in the 1970's, 76 AM. ECON. REV. 141, 151-53 (1986) (more recent economic research showing the same causal link). All of this research has roots in Solow's Nobel Prize winning work, which demonstrated that most of the economic growth in the United States in the first half of this century could be explained by investments in research and development and education rather 
Although the existence of the patent system's impact is beyond dispute, the exact nature of this impact remains a topic of significant debate. ${ }^{5}$ Proponents of the system credit it with bolstering the national economy by fostering invention and its commercialization. ${ }^{6}$ Detractors of the system argue that alternatives would do an even better job and should therefore be used instead. ${ }^{7}$

Specific foci of this general debate have recently emerged around several controversial trends in the patent system that have attracted great attention in the legal, technology, economics, and business communities. For example, some question changes in the patent system that are perceived to have increased predictability in patent litigation and certainty in patent law, such as the creation of the United States Court of Appeals for the Federal Circuit in 1982 and several areas of that court's case law. ${ }^{8}$ Others question the now routine use of pat-

than by increases in capital and labor. See Robert M. Solow, Technical Change and the Aggregate Production Function, 39 REV. ECON. \& STAT. 312, 320 (1957). Solow's work is extended in this connection by Romer, who argues that such investment in research and development and education is unlike other forms of investment in that it does not experience decreasing returns to scale. See Paul M. Romer, Increasing Returns and Long-Run Growth, $94 \mathrm{~J}$. POL. ECON. 1002, 1003 (1986). The more one puts in, the more one gets out, and the "bang for the buck" does not decrease as more and more bucks are added.

5. See, e.g., 8 RESEARCH IN LAW AND ECONOMICS, THE ECONOMICS OF PATENTS AND COPYRIGHTS 1-129 (John Palmer \& Richard O. Zerbe eds., 1986) (presenting the views of multiple authors critically reviewing economic theories about the merits of a patent system); see also CHISUM ET AL., supra note 2, at 50-72 (collecting sources and reviewing economic theories about how the patent system operates).

6. See, e.g., 8 RESEARCH IN LAW AND ECONOMICS, The ECONOMICS OF PATENTS AND COPYRIGHTS, supra note 5, at 1-129 (collecting and reviewing arguments by proponents of the patent system).

7. See, e.g., id. (collecting and reviewing arguments by detractors of the patent system).

8. See, e.g., Ian Ayres \& Paul Klemperer, Limiting Patentees' Market Power Without Reducing Innovation Incentives: The Perverse Benefits of Uncertainty and Non-Injunctive Remedies, 97 MICH. L. REV. 985, 986-89 (1999) (criticizing recent increases in certainty in patent law due to the Federal Circuit's expanded use of preliminary injunctions and the other courts' adherence to the property right view of patents as an absolute right to exclude); see also infra Part II.C. The Court of Appeals for the Federal Circuit, created in 1982, has jurisdiction over appeals in all patent cases throughout the country, regardless of whether they arise from trials in the federal district courts or from proceedings before the Patent and Trademark Office. See Federal Courts Improvement Act of 1982, Pub. L. No. 97-164, § 127, 96 Stat. 25, 37 (1982) (creating a unified forum for patent appeals in the Federal Circuit by merging the Court of Claims with the Court of Customs and Patent Appeals and transfer- 
ents to protect subject matter that many previously considered to be ineligible for patent protection, such as living organisms, gene fragments, computer software, and financial services. ${ }^{9}$

ring to the new court jurisdiction over appeals from patent cases that were tried in the district courts). The creation of such a unified forum for patent appeals was not without debate. See, e.g., Gerald J. Mossinghoff, The Creation of the Federal Circuit, in CHISUM ET AL., supra note 2, at 29 (providing discussion by a former Patent and Trademark Office Commissioner about the impact of the Federal Circuit on efforts to bring certainty and stability to U.S. patent law); cf. Rochelle Cooper Dreyfuss, The Federal Circuit: A Case Study in Specialized Courts, 64 N.Y.U. L. REV. 1, 4-5 (1989) (discussing contested issues surrounding the creation of the Federal Circuit). Indeed, the Federal Circuit has increased certainty in the patent system in general through landmark decisions in several discrete areas of the court's case law and has consistently reaffirmed the nature of the patent right as a property right, with an absolute right of exclusion that is clearly defined and marked by clear and fixed boundaries. See, e.g., Markman v. Westview Instruments, Inc., 52 F.3d 967, 979 (Fed. Cir. 1995) (en banc), aff d, 517 U.S. 370 (1996) (holding the construction of patent claims to be a question of law, not fact, and subject to de novo review by only one intermediate court of appeals, the Federal Circuit); Vitronics Corp. v. Conceptronic, Inc., 90 F.3d 1576, 1582-85 (Fed. Cir. 1996) (reviewing strict recipe for the use of various forms of evidence in construing patent claims); Polaroid Corp. v. Eastman Kodak Co., 833 F.2d 930, 931 (Fed. Cir. 1986) (refusing to stay an injunction pending appeal after recognizing that the public policy interest in protecting rights secured by the patent outweighs the public demand for increased quantity of a good presently covered by a patent); Amgen, Inc. v. Chugai Pharm. Co., 927 F.2d 1200, 1212-13 (Fed. Cir. 1991) (applying the statutory requirement of 35 U.S.C. $\$ 112$ that the text of the patent application as filed contain sufficient disclosure to enable one in the art to make and use whatever is covered by patent claims as eventually issued); Vas-Cath, Inc. v. Mahurkar, 935 F.2d 1555, 1563-64 (Fed. Cir. 1991) (holding that 35 U.S.C. $§ 112$ requires the text of the patent application as filed to satisfy the separate and distinct written description requirement so as to reasonably convey to those in the art exactly what is covered by the patent claims as eventually issued); Amgen v. Chugai, 927 F.2d 1200 (applying a separate written description requirement to claims in the field of biotechnology); Fiers v. Revel, 984 F.2d 1164, 1169-71 (Fed. Cir. 1993) (solidifying the court's position on a separate written description requirement); Regents of the Univ. of Cal. v. Eli Lilly \& Co., 119 F.3d 1559, 1566 (Fed. Cir. 1997) (solidifying further the court's position on a separate written description requirement); Lockwood v. Am. Airlines, Inc., 107 F.3d 1565, 1571-72 (Fed. Cir. 1997) (applying the same written description requirement to the field of computer software); Gentry Gallery, Inc. v. Berkline Corp., 134 F.3d 1473, 1478-80 (Fed. Cir. 1998) (holding that the written description requirement is not limited to complex technologies and applies equally to simple technologies, like sofa recliners); see also infra text accompanying notes $115,170$.

9. See, e.g., Michael A. Heller \& Rebecca S. Eisenberg, Can Patents Deter Innovation? The Anticommons in Biomedical Research, 280 SCI. 698, 698-701 (1998) (criticizing the availability and use of patents on gene fragments and other biological materials); James Gleick, Patently Absurd, N.Y. TIMES, Mar. $12,2000, \S 6$ (Magazine), at 44 (criticizing the expanding use of patents in ecommerce); Seth Shulman, Software Patents Tangle the Web, TECH. REV. Mar./Apr. 2000, at 68 (discussing the technology community's views on the 
In reaction to these recent trends in the patent system, several critics have suggested that the system's goals can be better achieved by implementing a variety of approaches that avoid or mitigate the potentially output-restricting monopolytype impact of property rights. Suggested approaches include cash rewards, ${ }^{10}$ buy-outs, ${ }^{11}$ and the use of liability rules, ${ }^{12}$ as distinct from property rules. This article uses the important

pros and cons of software patents); William Falloon, Patent Power: Who Owns the Ideas that Drive Derivatives, RISK, Dec. 1999, at 22 (discussing the story behind Columbia University's patent for the quasi-Monte Carlo method of valuing derivatives and the financial community's views on the larger debate over financial patents); see also infra text accompanying notes 112-15, 203-12. See generally CHISUM ET AL., supra note 2, at 729-893 (reviewing shifts in patent law's requirements of utility and statutory subject matter and collecting diverse commentaries from legal, technology, and business communities defending and criticizing these shifts). Today, as a matter of positive law, there is no per se exception to patents on living things, computer software, or business methods. See Diamond v. Chakrabarty, 447 U.S. 303, 315 (1980) (holding that living organisms are patentable subject matter); Diamond v. Diehr, 450 U.S. 175, 176 (1981) ("A claim drawn to subject matter otherwise statutory does not become nonstatutory simply because it uses a mathematical formula, computer program, or digital computer."); In re Alappat, 33 F.3d 1526, 1544 (Fed. Cir. 1994) (en banc) (holding that a computer system for producing a smooth waveform on a raster display is patentable subject matter); State St. Bank \& Trust Co. v. Signature Fin. Group Inc., 149 F.3d 1368, 1373-74 (Fed. Cir. 1998), cert. denied, 525 U.S. 1093 (1999) (holding that a hub and spoke mutual fund accounting system is patentable subject matter).

10. See generally, e.g., STEVEN SHAVELl \& TANGUY VAN YPERSELE, REWARDS VERSUS INTELLECTUAL PROPERTY RIGHTS, NATIONAL BUREAU OF ECON. RESEARCH WORKING PAPER NO. 6956 (1999) (suggesting a system of government-sponsored cash rewards instead of or in addition to a system of patents and highlighting advantages of such a system to fields where the disparity between average cost and marginal cost is typically large, citing in particular fields previously considered by some to be largely ineligible for patent protection, like modern biotechnology products and computer software). For further discussion of the cash rewards system, see infra Part I.

11. See generally, e.g., MICHAEL KREMER, PATENT BUY-OUTS: A MECHANISM FOR ENCOURAGING INNOVATION, NATIONAL BUREAU OF ECON. RESEARCH WORKING PAPER NO. 6304 (1997) (suggesting a system in which the government buys out patents after conducting an auction to determine an appropriate buy-out price and highlighting advantages of such a system to fields where the disparity between average cost and marginal cost is typically large, citing in particular fields previously considered by some to be largely ineligible for patent protection, like modern biotechnology products and the design of computer chips). For further discussion of the cash rewards system, see infra Part I.

12. See, e.g., Ayres \& Klemperer, supra note 8, at 1020-23 (suggesting that patents be enforced through liability rules, under which infringement is permitted but generates a damage award to rights-holders, instead of property rules, under which rights-holders enjoy an absolute right to enforce their rights through injunctions); see also infra Part II.C. 
contributions made by these commentators to reveal shortcomings in any view of the patent system that focuses only on incentives to engage in inventive activity. ${ }^{13}$

This Article offers a new view of the patent system that embraces property rights and property rules as essential elements for achieving core goals of the patent system, and forges a surprising link among disparate features of the system previously considered to be unrelated or even mutually antithetical. ${ }^{14}$ According to this view, the treatment of patents as property rights is necessary to facilitate investment in the complex, costly, and risky commercialization activities required to turn nascent inventions into new goods and services. ${ }^{15}$ Furthermore, property treatment is equally necessary to help society decide which inventive activities are worth protecting in the first instance. ${ }^{16}$

Such a commercialization view not only reveals how the recently suggested alternatives ${ }^{17}$ fail to address these important goals of the patent system and would actually frustrate them ${ }^{18}$ but it also shows how the current system already addresses the concerns raised by such commentary. ${ }^{19}$ This Article argues that the power to restrict use that is conferred by a patentee's property right ${ }^{20}$ and the strict enforcement of this right with a property rule, rather than a liability rule, ${ }^{21}$ are paradoxically essential to avoiding underuse. This Article also argues that the ability to use price discrimination to avoid the dead-weight loss potentially caused by a property owner's power over price ${ }^{22}$

\footnotetext{
13. See discussion infra Part I.

14. See discussion infra Parts I-II.

15. See discussion infra Part I.A.

16. See discussion infra Part I.B.

17. See supra text accompanying notes 10-12.

18. See discussion infra Part I.

19. See discussion infra Part II.

20. See discussion infra Part II.A.

21. See discussion infra Part II.C.

22. See discussion infra Part II.B. Dead-weight loss refers to the loss in potential social wealth when a competitive market is compared to an otherwise identical market in which there is monopoly power, or power over price. In a competitive market for a product, society is made better off by sales of such a product through the creation of both a producer surplus and a consumer surplus. These forms of surplus can be understood through an example in which there is an efficient market for ice cream cones and a wealthy adult and an average child each consuming the same size cone in that market. The market sets the price for the cone. Although the child may value the cone at about its price, the wealthy adult may value the cone much more than the
} 
and the ability to use patents as tools for avoiding or challenging monopolies ${ }^{23}$ are essential to explaining the perceived paradox of strong patent laws persisting in the face of antitrust laws.

This Article further shows how the commercialization view's link among patents, property rights, and price discrimination also operated to inform and motivate the framers of our current patent system. ${ }^{24}$ This Article then shows how such a commercialization view may help explain many controversial trends in the existing patent system, including those that sparked the recent critical commentary. ${ }^{25}$ This view also helps explain similar controversial trends in other intellectual property regimes such as trademarks. ${ }^{26}$

price. Each consumer receives a benefit for exchanging money for cone, which is why the exchange is made voluntarily, but some consumers may value the exchanged good substantially above the exchange price. Consumer surplus represents the aggregate amount that all consumers in the market are made better off by the exchanges made at market price. More specifically, consumer surplus is the difference between what consumers are willing to pay and what they actually pay. In contradistinction, producer surplus is the difference between what a producer collects as payment for the good, the market price, and the marginal cost of producing that good. In this simple market, social surplus is the amount that producers and consumers in aggregate are made better off for having made the market exchange. In more dynamic and complex models, social surplus also includes any positive benefit that may flow to those who are external to the two-person exchange, so-called positive externalities. Kremer and Shavell and van Ypersele point out that the patent owner may not be able to capture the full social surplus of the invention because some will be enjoyed by others as consumer surplus or positive externalities. See KREMER, supra note 11, at 1; SHAVELL \& VAN YPERSELE, supra note 10, at 5-6. They also argue that some of the social surplus will be lost due to the monopoly power wielded by a patentee. See KREMER, supra note 11, at 1; SHAVELL \& VAN YPERSELE, supra note 10, at 5-6. In a typical monopoly market, the monopolist restricts output so that a higher price can be charged. This shift in price and output causes some consumer surplus in the competitive market to become producer surplus, thereby making the monopolist better off than under the competitive market. The shift also causes some consumer surplus and some producer surplus to be lost. This combined loss is the so-called deadweight loss of a monopoly market and represents a net decrease in social surplus due to the shift from competitive to monopoly markets. For a more detailed discussion of the comparison between monopoly and competitive markets in the context of inventions, see CHISUM ET AL., supra note 2, at 50-58.

23. See infra text accompanying notes 199-202.

24. See discussion infra Part III.

25. See discussion infra Part IV.

26. See discussion infra Part V. 


\section{PROBLEMS WITH REWARD ALTERNATIVES TO PATENTS}

Some critics of the patent system have argued that permitting inventors to leverage the patent right to exclude in exchange for royalties (or injunctions and damages) is a sloppy reward for inventive effort. ${ }^{27}$ The inventor may be unable to recoup the full social surplus created by the invention. ${ }^{28}$ For example, the lure of market power may cause investment in inventive activity to exceed social surplus. ${ }^{29}$ And the patent's power to restrict output and raise price may create dead-weight loss. ${ }^{30}$ Instead, Shavell and van Ypersele, ${ }^{31}$ and Kremer, ${ }^{32}$ among others, offer different systems designed to improve the match between social surplus and the amount an inventor will recoup while simultaneously avoiding the patent's potential power over price and its commensurate dead-weight loss. These critics offer two alternatives to the current patent system. The general features of the offered alternatives are first outlined individually below. The details of their implications are subsequently discussed together.

Shavell and van Ypersele suggest a system of cash rewards paid by the government to inventors. ${ }^{33}$ Under this system, in-

27. See, e.g., KREMER, supra note 11 , at 1-5; SHAVELL \& VAN YPERSELE, supra note 10, at 1-8. Technological progress is a complex and multi-step process. To be sure, the act of inventing is essential, but it is only one of the early steps in the process. At a minimum, members of society other than the original inventor must receive some benefit from nascent inventions before society at large can be considered to have enjoyed technological progress. Such benefit may be in the form of information about the invention, a product of the invention, or a useful embodiment of the invention. The collective act of transmitting benefit from nascent inventions to those other than the inventor is here referred to as commercialization. This Article offers a view of the patent system that is tied to commercialization, rather than to inventing. For more on the commercialization process itself, see discussion infra Part I.A.

28. See KREMER, supra note 11 , at 1-5; SHAVELL \& VAN YPERSELE, supra note 10, at 1-8. Social surplus is the amount of total social welfare generated by the invention less the costs of making the invention, such as research by the inventor and the inventor's competitors. Social welfare is the aggregate value of all utility that individuals obtain from the invention.

29. See KREMER, supra note 11, at 1-5; SHAVELL \& VAN YPERSELE, supra note 10 , at $1-8$.

30. See KREMER, supra note 11 , at 1-5; SHAVELL \& VAN YPERSELE, supra note 10 , at $1-8$.

31. See SHAVELL \& VAN YPERSELE, supra note 10, at 1-8 (suggesting the government give cash rewards instead of or in addition to patents).

32. See KREMER, supra note 11, at 1-5 (suggesting the government step in to buy out patents after they have been issued).

33. See SHAVELL \& VAN YPERSELE, supra note 10 , at 1. 
ventions pass immediately into the public domain, becoming freely available to all. ${ }^{34}$ The government would then set the amount of reward based on information about demand in the form of actual sales data gathered after the invention is made. ${ }^{35}$ Importantly, Shavell and van Ypersele demonstrate that the government's use of actual sales data gathered after an invention is made will most likely yield better information about demand than any special knowledge possessed by the inventor before deciding whether to engage in the inventive activity. ${ }^{36}$ Shavell and van Ypersele conclude that a patent system does not enjoy any fundamental advantage over a reward system. ${ }^{37}$ They further conclude that a mixed system under which the innovator is allowed to seek either a patent or a reward is superior to a system offering only patents. ${ }^{38}$

Kremer similarly suggests a system in which the government pays patentees to return their patents to the public domain. ${ }^{39}$ He calls this a system of patent buy-outs. ${ }^{40}$ As in the Shavell and van Ypersele system, patents that have been bought out under Kremer's system will pass immediately into the public domain with their claimed inventions becoming freely available to all. ${ }^{41}$ Under Kremer's system, the government would use an auction to estimate the private value of patents. ${ }^{42}$ The government would buy out most patents put to auction, but in order to induce bidders to reveal their true evaluations, a few patents would be sold to bidders. ${ }^{43}$ Because bidders would not know which patents would be purchased, they would have incentives to value them all honestly. ${ }^{44}$ Kremer concludes that it is impossible to know based on theory alone whether patent buy-outs would provide a useful supple-

34. See id. Shavell and van Ypersele propose that instead of granting a patent, the government should pay a cash reward funded by general tax revenues. Id. Because the heart of the patent right is the right to exclude, see 35 U.S.C. $§ 154(a)(1)(1994)$, absent patents, everyone would be free to make and use the invention, unless of course there existed prohibitions from other areas of law, such as food and drug or environmental law.

35. See SHAVELL \& VAN YPERSELE, supra note 10, at 21-22.

36. See id. at 22 .

37. Id. at 1 .

38. Id.

39. KREMER, supra note 11 , at 1 .

40. Id.

41. Id. at 2 .

42. Id.

43. Id.

44. Id. 
ment to the existing patent system. ${ }^{45}$ However, he recommends a limited trial to better evaluate the proposal. ${ }^{46}$

Before unpacking the detailed implications of these two proposed alternatives to the patent system, it must be recognized that they are offered through substantial papers presenting mathematical economic models that do elucidate several larger issues. Most importantly, the models demonstrate that rewards - whether cash, praise, or otherwise, and whether given by the government or a private actor-can operate like patents as tools for promoting inventive activity. This Article does not address the relative strengths of the many available tools for promoting inventive activity. Rather, the section that follows addresses the relative strengths of rewards and patents in promoting the larger process of technological progress through invention commercialization.

\section{A. Commercialization}

Any system focused on rewarding inventive effort, when an actual good or service is brought to the market, runs the risk of failing to address the activities that take place after an invention is made but before it can be profitably exploited. ${ }^{47}$ The in-

45. Id. at 46. As an alternative to the proposed cash reward and buy-out systems, the government could act through the tax system by providing a tax credit, for example. See, e.g., OfFICE OF TECHNOLOGY Assessment, U.S. CONGRESS, INNOVATION AND COMMERCIALIZATION OF EMERGING TECHNOLOGY 90-94 (1995) [hereinafter INNOVATION AND COMMERCIALIZATION OF EMERGING TECHNOLOGY] (discussing the influence of tax and credit provisions on invention commercialization).

46. INNOVATION AND COMMERCIALIZATION OF EMERgING TECHNOLOGY, supra note 45 , at $90-94$.

47. See id. at 3, 20-96 (collecting sources and setting forth as principle findings and describing in detail how successful commercialization is not simply a matter of developing technology first or getting to market first, but instead requires intellectual property protection to create an environment conducive to securing complimentary assets, skills, capital, manufacturing, marketing, and support); cf. CHISUM ET AL., supra note 2, at 62-72 (collecting sources and reviewing diverse incentive theories of the patent system including "incentive to invent," "incentive to disclose," "incentive to commercialize," and "incentive to design around"). The incentive to commercialize theory discussed herein is similar in some respects to the "prospect" theory elucidated by Kitch, which views the patent as important in providing incentives for investment in increasing the value of a patented technology. See Edmund W. Kitch, The Nature and Function of the Patent System, 20 J.L. \& ECON. 265, 276-77 (1977). The view offered in this Article is not critical of the approach offered by Kitch. Instead, this Article offers an alternative to Kitch's analysis that links together three different sets of literature not addressed in his work and not previously interconnected: the patent law and economics literature leading 
vention must be developed into some commercial embodiment. ${ }^{48}$ Capital may have to be raised. ${ }^{49}$ Production facilities and labor must be made available. ${ }^{50}$ Distribution channels must be created. ${ }^{51}$ Consumers must be educated about the existence and benefits of this new good or service. ${ }^{52}$ Each of these activities requires investment from the holder of the invention, and many others, such as product development teams, investment bankers, venture capitalists, labor sources, and advertisers. ${ }^{53}$ As each of these people moves into action to make such investments (so-called first movers), there may be numerous other market participants (so-called second movers) who subsequently move to compete at each step of the larger endeavor. Some of the costs borne by a first mover also would be borne by any second mover. Some costs, however, will be borne only by the first mover, because once incurred they will yield benefits for the entire class of competitors, embracing first movers and second movers. ${ }^{54}$

Second movers generally enjoy numerous advantages over the first movers against whom they compete. ${ }^{55}$ Consider, for

up to the framing of the present patent system that is codified in the 1952 Patent Act, see discussion infra Part III; the law and economics literature on property rights and property rules, like that of Demsetz, see discussion infra Part II; and the component of the contemporary law and economics literature that is critical of recent trends in the patent system, like that discussed infra in Parts I-II. This Article also resurfaces the important screening, see infra text accompanying notes 71-78, and potential monopoly-challenging, see infra text accompanying notes 199-202, functions of the present patent. The commercialization label is used here in deference to its use by the framers of the current patent system around the time the system was drafted. See discussion infra Part III. See also infra text accompanying note 189 (using "commercialize" label).

48. InNOvation AND COMMERCIALIZATION OF EMERging TECHNOLOGY, supra note 45 , at $3,20-96$.

49. Id.

50. Id.

51. Id.

52. Id.

53. Id.; see also Joseph A. SChUMPETER, THE THEORY OF ECONOMIC DEVELOPMENT 61-94 (1983) (discussing the important role of market power like that afforded by a patent's right to exclude in organizing invention commercialization activity) [hereinafter SCHUMPETER, THE THEORY OF ECONOMIC DEVELOPMENT]; JOSEPH A. SCHUMPETER, CAPITALISM, SOCIALISM, AND DEMOCRACY 81-110 (3d ed. 1950) (same) [hereinafter SCHUMPETER, CAPITAlism, SOCIALISM, AND DEMOCRACY]; SCHUMPETER, Business CyCles, supra note 4 , at 84-192 (same).

54. See id.

55. See id. See generally Joseph Farrell \& Garth Saloner, Standardiza- 
example, that a second mover's mere knowledge of a first mover's success eliminates a great deal of risk from the second mover's decision whether to embark on the same enterprise. ${ }^{56}$ The mere knowledge that a problem has been solved may provide psychological motivation to attempt a solution. ${ }^{57}$ In addition, successfully developed products and distribution channels are by their nature difficult to keep secret and can serve as working models for competitors to follow, thereby saving them the cost of weeding out worse alternatives. ${ }^{58}$ Furthermore, the costs of capital will decline throughout the industry because investors will become educated about its specific risks and potential for profit. 59 Similarly, the education of consumers and arousal of consumer demand will benefit all competitors equally. ${ }^{60}$ Indeed, the arrival of a competitor into the market will force the first mover to incur added costs of brand advertising, on top of the costs of more general product advertising already incurred. ${ }^{61}$

tion, Compatibility and Innovation, 16 RAND. J. ECON. 70, 75-79 (1985) (describing second-mover advantages); Joseph Farrell \& Garth Saloner, Competition, Compatibility and Standards: The Economics of Horses, Penguins and Lemmings, in PRODUCT STANDARDIZATION AND COMPETITIVE STRATEGY $1(\mathrm{H}$. Landis Gabel ed., 1987) (providing illustrative examples of second-mover advantages).

56. See generally ROBERT S. PINDYCK \& DANIEL L. RUBINFELD, MICROECONOMICS 149 (1989) (discussing the value of information in reducing uncertainty generally).

57. This may be due in part to risk aversion. See id. at 139 (discussing attitudes toward risk). At the least, it is often easier to solve a problem once it is known to be solvable.

58. Trade secrecy is not a viable means for protecting anything that can be easily reverse engineered. Cf. E.I. duPont deNemours \& Co. v. Christopher, 431 F.2d 1012, 1015 (5th Cir. 1971) (drawing a distinction between information voluntarily disclosed for which there is no trade secret protection and the use of industrial espionage to improperly peer into a competitor's trade secret safe).

59. See INNOVATION AND COMMERCIALIZATION OF EMERGING TECHNOLOGY, supra note 45 , at 3, 20-96.

60. This type of second-mover advantage can be mitigated by the first mover's proper trademark use, in which the mark is always accompanied by a generic description. See SIEGRUN D. KANE, TRADEMARK LAW: A PRACTITIONER'S GUIDE $\S 4: 2.1[\mathrm{~A}]$ (1999) (discussing the importance of proper trademark use in avoiding possible loss of rights in the mark by letting it become a generic term).

61. Investments in brand name recognition and consumer goodwill are typically stored in a company's trademarks, which indicate to consumers that the marked products come only from one particular source. See id. § 1:1.1 (describing trademarks as identifiers of source and vessels of goodwill). 
The patent right to exclude competitors who have not shared in bearing these initial costs provides incentives for the holder of the invention and the other players in this market to come together and incur all costs necessary to facilitate commercialization of the patented invention. ${ }^{62}$ Therefore, although a simple reward for inventive effort might provide adequate incentives for invention itself, the nascent invention may never reach a single consumer without the above incentives to commercialize. ${ }^{63}$

The Shavell and van Ypersele system seems to contemplate that at least some amount of commercialization will be allowed to take place because the amount of reward is to be based on data from actual sales. ${ }^{64}$ But their suggested system does not make clear how far along the commercialization chain the invention must have progressed before a reward will accrue. The reward will fail to provide incentives for complete commercialization if a right to it is given too soon after the completion of invention and commencement of commercialization. ${ }^{65}$

If the moment of entitlement to the reward is pushed later along the commercialization timeline, then the reward will generate some bad, rent-dissipating effects. Rent dissipation occurs when the lure of a reward causes too many individuals

62. The patentee, and indeed anyone who has incurred such initial costs, will want to charge a price for the invention or its embodiments that includes both the marginal cost of producing each additional unit of output as well as these fixed costs of initial development. A second mover who has not incurred such initial costs will be able to charge a lower price that is based only on the marginal cost of producing each additional unit of output. Without the right to exclude, the patentee would also have to charge this lower price as well or lose all sales to the competitor. Because the patent right to exclude allows the patentee to charge the higher price, the availability of this right provides incentives for the holder of the invention to incur these costs. The ability to obtain an assignment or license from the patentee similarly provides incentives for the other players in the market to incur such costs, in a cooperative fashion. Optimally, each step in the commercialization process is carried out by the lowest cost provider of that service.

63. The suggested reward alternatives do not explain how a reward system would operate in practice. More particularly, it is not clear how soon after the invention is made the reward would be given or the right to a reward would attach. If the right to a reward attaches immediately after the invention is made, then the reward will only provide incentives for inventive activity and not incentives for commercialization.

64. See supra text accompanying notes 33-38.

65. It is not clear that any individual will have adequate incentives to invest in commercializing an invention for which a reward, and not a patent, has been issued if the right to the reward attaches to the one who completes the invention. 
to engage in the rewarded activity. ${ }^{66}$ Some rent dissipation may be due to an increase in the size of the reward.67 In the case of rewards for inventions, as the entitlement to the reward is pushed later along the commercialization timeline, the size of the reward will have to increase to cover the costs of some commercialization activity in addition to inventive activity.

The shift down the commercialization timeline of the entitlement to the reward will also increase the uncertainty over who will be a reward recipient. As this uncertainty increases, the invention-inducing power of the reward may decrease, or the undesirable rent-dissipating power may increase. The desirable, invention-inducing power of the reward may decrease because each individual would-be inventor may find the possibility of reward to be too low to induce investment in the inventing enterprise. Alternatively, the undesirable, rentdissipating power may increase as the increase in uncertainty causes even more individuals to gamble on inventive activity in the hopes of winning the reward. ${ }^{68}$

Shavell and van Ypersele argue that the patent system and the reward system both face equal problems with such rent dissipation. ${ }^{69}$ While both systems may induce a race at the invention stage, however, the race under a reward system in which the entitlement to reward attaches late in the commercialization process will continue through the commercialization stage.

66. For example, the possibility of winning a reward for inventing may induce more than the optimal number of people to incur the costs of attempting to invent. As a result, although each individual may rationally decide to make such an attempt because the reward is greater than that individual's private costs, so many individuals may make attempts that the aggregate costs of inventing may exceed the invention's social surplus. See generally Mark F. Grady \& Jay I. Alexander, Patent Law and Rent Dissipation, 78 VA. L. REV. 305 (1992) (discussing rent-seeking, and therefore rent-dissipating, behavior surrounding inventions). Under the present patent system, in cases where an invention has been independently invented by more than one person, only one inventor, if any, may receive a patent for that invention. See 35 U.S.C. $\$ 102(\mathrm{~g})$ (1994) (setting forth the statutory basis for contests over priority of invention called "interferences").

67. See Grady \& Alexander, supra note 66, at 321 (discussing the connection between the size of reward and the extent of rent dissipation).

68. This seemingly irrational behavior may occur for the same reason that individuals decide to buy lottery tickets. The decision to buy lottery tickets is irrational if the calculation only includes cost of ticket and benefit associated with the likelihood of cash reward. The decision may be rational if it takes into account the psychological benefit some people enjoy from simply buying a ticket even in the face of poor odds.

69. SHAVELL \& VAN YPERSELE, supra note 10, at 23. 
The rent-dissipating impact that results will also be worse. Thus, as compared with a reward system, the patent system may be not only better able to improve coordination among market players engaged in the invention commercialization process, it also may be better able to avoid rent dissipation. ${ }^{70}$

The reward alternatives, however, face additional problems beyond coordination and rent dissipation. The problem of identifying reward recipients is itself a significant problem. As discussed in the next section, the problem of selecting reward recipients reveals both a significant practical hurdle to the implementation of reward systems and a particularly elegant feature of the patent system.

\section{B. SCREENING}

A central flaw in reward systems is their failure to address the important role played in the current system by competitors of the patentee. The threat of an injunction by a federal court draws a competitor's careful attention to issues of validity. Both liability and injunction can be completely avoided by a showing that the claimed invention was not in the first instance "worth to the public the embarrassment of an exclusive patent." 71 Validity issues may be raised as a complete defense to an infringement suit or may support their own declaratory judgment action. ${ }^{72}$ In either case, the patentee's competitors serve an important policing function in the patent system by searching out and bringing to bear the best information they can find about a patent's validity. ${ }^{73}$ Validity-destroying information-such as prior art-may be in the possession of the

70. See generally Grady \& Alexander, supra note 66 (discussing a patent's role in limiting post-invention rent-seeking, and therefore rent-dissipating, behavior).

71. Letter from Thomas Jefferson, supra note 2, at 1292.

72. See 35 U.S.C. § 282 (1994)

73. Competitors of the patentee often are well informed about the field of endeavor and have different information than the patentee. Patent examination is an ex parte proceeding and only the prior art known by the applicant and the examiner are considered when assessing patentability. Although issued patents are presumed valid, information not considered by the Patent Office is often instrumental in a court order of invalidity. The federal courts, not the Patent Office, are the final arbiter of validity. E.g., Quad Envtl. Techs. Corp. v. Union Sanitary Dist., 946 F.2d 870, 875-76 (Fed. Cir. 1991) ("The courts are the final arbiter of patent validity and, although courts may take cognizance of, and benefit from, the proceedings before the patent examiner, the question is ultimately for the courts to decide, without deference to the rulings of the patent examiner."). 
competitor, or it may be found only after scouring public and private sources around the world.

Shavell and van Ypersele maintain that the government may have better information concerning the ultimate market demand for a product after sales have occurred than a patentee would have before deciding to invent. ${ }^{74}$ The existence of market demand, however, does not establish that the invention itself would have been patentable, and no market participant would have an adequate incentive to provide the government with information relating to patentability. ${ }^{75}$ In addition, the government's ability to uncover such information itself may be substantially less than that of a competitor under the current system, especially where the competitor possesses the information. ${ }^{76}$

It is possible that Shavell and van Ypersele are not concerned with validity issues. For example, their system of rewards may be indifferent between new technologies and revived ones. Rewards, however, would be very difficult to dole out in such a system. Every market having large demand would generate droves of reward claimants each asserting to have made some contribution. Thus, reward systems face the serious practical hurdle of having to develop an effective

74. SHAVELL \& VAN YPERSELE, supra note 10 , at 22.

75. Individual taxpayers would face an enormous collective action problem, each one facing only a minute pro-rata benefit while bearing the entire search cost. Although those who would be rival claimants to inventor status in a patent system would present themselves as rival claimants to the cash reward, contests among rival claimants to a patent (called interference proceedings) are relatively rare compared with challenges to validity based on lack of novelty, obviousness, or inadequate disclosure. See, e.g., 1987 Committee Report, 1987 A.B.A. SEC. PAT. TRADEMARK \& COPYRIGHT L. 64 (noting that the interference practice in the United States in 1987 typically involved less than $0.25 \%$ of all patent applications, or about three hundred of the approximately 130,000 applications filed each year).

76. Additional evidence supporting this point can be found in the example of the present Patent and Trademark Office, which issues numerous patents that are later found invalid by a federal court based on prior art not uncovered during examination. See supra note 73 and accompanying text. This occurs even though the Patent Office is funded through user fees and is not resource constrained, generating a budget surplus of over $\$ 70$ million per year. See PTO Fees Will Remain With Agency, Under FY 2000 Budget Plan, Dickinson Says, 57 PAT. TRADEMARK \& COPYRIGHT J. 282, 282 (1999) (discussing Patent Office funding and the budget surplus). Implicit in the commercialization view of the patent system offered in this Article is the understanding that the Patent Office is not malfunctioning when it issues such patents. Indeed, according to this view, the system is not operating grossly out of tune with its design. 
method for deciding how to allocate the rewards among all such possible claimants. ${ }^{77}$

In contradistinction, the patent system does not face such a hurdle. The same core legal rules that drive the patent system simultaneously provide the system with its own method for deciding which inventive activities are eligible to receive the benefit of a patent. The tests of novelty, nonobviousness, and adequacy of disclosure serve this decisional function for the patent system, and they discipline the system through litigation and its threat. ${ }^{78}$

A system of patent buy-outs offered by Kremer may provide a solution to the validity problem faced by the cash reward model. ${ }^{79}$ Under Kremer's proposal, the government would use an auction to estimate the private value of patents. ${ }^{80}$ The government would buy out most patents put to auction, but in order to induce bidders to reveal their true evaluations, a few patents would be sold to bidders. ${ }^{81}$ Because bidders would not

77. The problems with allocating rewards or any other kind of kudos for good results are legion. Consider the general problem of allocating fame:

What exactly constitutes an honest fame, what a dishonest fame?

What are the rules, criteria, precepts, principles, if there be any, by which we decide whom to accord how much glory for what achievement, and by which we decide who has laid claim to fame that isn't his? Are there such rules, and do they span the full range of moral, scientific, and artistic accomplishments for which glory is bestowed?

LEO KatZ, ILl-GotTen Gains: Evasion, BlackMaIl, Fraud, AND KindRED PUZZLES OF THE LAW 200 (1996). Katz uses societal rules for blame embodied in the criminal law to attempt to derive societal rules for fame. See id. at 201 (describing the symmetrical relationship between societal rules of praise and blame). Concerning the distinction between acts and omissions, one might ask what level of contribution is required on the part of a supervising faculty member for co-authorship or co-inventorship. Is active advice required, or is passive permission and non-interference sufficient where others would have refused to allow or continue a project? $C$. id. at 201-03 (discussing the significance of affirmative acts, omissions, and motive in establishing the principles of praise). Also consider how the rules of praise should evaluate the problems presented by cases of mere thought, transferred intent, or unreasonable hopes, any of which might nonetheless correlate with inventive success. $C f$. id. To what extent should originality, effort, genius, or utility drive our decisions to allocate rewards? Cf. id. at 203-04 (describing the tension between originality and utilitarianum as the basis of rewards for scientific progress).

78. Cf. infra text accompanying note 195 (arguing that the desire to obtain a broad-reaching patent is moderated by the vulnerability of such a patent on various validity grounds in litigation).

79. See KREMER, supra note 11 , at 1 .

80. Id. at 2 .

81. Id. (explaining that the government would randomly select a few patents to be sold to the highest bidder). 
know which patents would be purchased, they would have incentives to value them all honestly. ${ }^{82}$ Like cash rewards, patent buy-outs would operate to eliminate the patentee's potential power over price and its commensurate dead-weight loss. ${ }^{83}$

The informational advantage of Kremer's proposal over a system of cash rewards comes from the fact that the bidders in Kremer's system are potential patent owners. Before bidding, such potential owners will be sure not only to acquire information about the market demand for the invention claimed in the patents but also about patent validity. Indeed, the incentives for such bidders to acquire information about validity will be similar to the incentives facing potential infringers under a patent system. ${ }^{84}$ Thus, the valuation set by Kremer's system will be better or more cheaply informed about issues of validity than the cash reward system offered by Shavell and van Ypersele.

Nevertheless, both proposed systems-rewards and buyouts-present the same timing paradox discussed earlier. ${ }^{85}$ To the extent the reward or buy-out is implemented soon after the invention is made, the systems fail to provide incentives for full commercialization, thereby preventing nascent inventions from reaching consumers. ${ }^{86}$ To the extent the reward or buy-out is implemented long after the invention is made, and presumably before the expiration of patent term, ${ }^{87}$ then incentives for some level of commercialization are present but both systems merely amount to a decrease in patent term with respect to their impact on subsequent commercialization.

It is possible that a decrease in patent term may not upset the patent system. To be sure, any particular systemic patent

82. Id.

83. Id. at 1-2.

84. Such bidders will want to acquire information about the patent's validity because the bidder may become the owner of the patent and have to rely on asserting the patent to recoup the price paid at the consummated sale of the patent. A purchased patent that was ultimately adjudicated invalid by a court would be a loss to the bidder who purchased that patent. See supra text accompanying note 73 .

85. See supra text accompanying notes 64-65.

86. See id.

87. The possibility of implementing the reward or buy-out so long after the invention is made that it is also after the expiration of patent term suggests use of the reward or buy-out as a mere adjunct to, not replacement for, the current patent system. Although this use must be considered in any balanced policy of industrial development, it is not the focus of the reward and buy-out systems offered by critics of the patent system. 
term represents an arbitrary compromise. Any term will satisfy a commercialization theory of the patent system if it remains sufficiently long and is fixed, publicly noticed, and otherwise inexpensive to administer. Kremer points out one way to compensate for a shortened term, which would be to add a multiplier of greater than one to the price reached at auction. ${ }^{88}$ Indeed, both Kremer and Shavell and van Ypersele argue that inventors do not reap the full social benefit of their inventions under a simple buy-out system (and to a lesser extent under the current patent system). ${ }^{89}$ The multiplier of Kremer's system includes a fixed markup to roughly cover the difference between the social and private values of inventions. ${ }^{90}$ Therefore, Kremer's proposal can be seen as an addition to the patent system characterized by shorter term and enhanced financial reward that may not be inconsistent with the commercialization theory. ${ }^{91}$ It could not work, however, without the patent sys-

88. See KREMER, supra note 11 , at $16-18$; see also SHAVELL \& VAN YPERSELE, supra note 10, at 1 . Kremer makes this multiplier suggestion in an effort to help ensure that the level of incentive provided more closely approximates the social value of the invention. See KREMER, supra note 11, at 16-18; see also SHAVELL \& VAN YPERSELE, supra note 10, at 1. Although his suggestion is motivated by concerns that the incentives provided to a patentee under the patent system are too low because of dead-weight loss, the suggestion may also be responsive to a decrease in incentives caused by shorter term. See id. Regardless of motivation, the enhanced price would serve to add the appropriate incentive to inventors without distorting the auction process because it would be paid by the government in the buy-out cases but not by bidders in the consummated sales cases.

89. See KREMER, supra note 11 , at $16-18$; see also SHAVELL \& VAN YPERSELE, supra note 10, at 1; id. at 5-6 (describing the inadequate incentive facing investors because even monopoly profits are likely to be less than the total social surplus generated by the invention).

90. An important contribution of Kremer's model is the conclusion that inventors do not reap the full social benefit of their inventions under either a simple buy-out system or the current patent system. See supra text accompanying note 28. It is for this reason that Kremer includes in his buy-out system a fixed markup to roughly cover this difference between the social and private values of inventions. See KREMER, supra note 11, at 1-5. Under Kremer's proposal, the market value of the patents would be determined through auction-he proposes a sealed-bid second-price auction to prevent collusion to increase price - and then the government would offer to buy patents at this private value times some constant markup, which would reflect the typical ratio of social to private value. See id. at 16-18.

91. Lichtman offers an alternative addition to the system in which the government offers a cash subsidy to any consumer who values a patented good above marginal cost but is unwilling or unable to pay to such a price. Douglas Gary Lichtman, Pricing Prozac: Why the Government Should Subsidize the Purchase of Patented Pharmaceuticals, 11 HARV. J.L. \& TECH. 123, 124-25 (1997). This proposal, however, faces the distortion and implementation con- 
tem operating in the first few years of patent term for those patents bought out by the government and operating full term for those patents for which the auction is consummated.

Thus, the commercialization view of the patent system reveals how the patent system is superior to the proposed reward and buy-out systems in both promoting invention commercialization and in deciding which inventive activities are eligible to receive some government-conferred benefit. Nevertheless, sponsors of the proposed alternatives to the patent system have responded to concerns about several important perceived shortcomings of the system that must be addressed. As discussed in the sections that follow, the commercialization view of the patent system also reveals how the current system obviates the concerns that motivated critics of the system in a way that is squarely consistent with core theories of property rights.

\section{PATENTS FOR COMMERCIALIZATION WITHOUT UNDERUSE}

The power to restrict use that drives the incentives for commercialization discussed in the previous section also gives rise to the central concern that motivated critics of the system: too little use may result. More particularly, this concern takes three forms. First, rights of exclusion in inventions will clog social ordering and bargaining around inventions. Second, the power over price conferred by a right to exclude may result in the creation of an overall dead-weight loss for society. Third, enforcement of the right to exclude might be better administered through a liability rule, rather than a property rule. The following sections address each of these concerns in turn.

\section{A. Property Rights to Avoid Underuse}

The creation of a property right to exclude others from partaking in the benefits of commercialization efforts is consistent with the basic thesis of Demsetz that property rights emerge when it becomes economically efficient to internalize benefits and costs. ${ }^{92}$ His most cited example is the emergence of property rights in land among Labradorian Indians as a response to overhunting. ${ }^{93}$ As Demsetz explains, after the creation of prop-

cerns generally raised against subsidies.

92. Harold Demsetz, Toward a Theory of Property Rights, 57 AM. ECON. REV. 347, 354 (1967).

93. See id. at 351-53 (asserting that a rise in demand for fur relative to 
erty rights, "an owner, by virtue of his power to exclude others, can generally count on realizing the rewards associated with husbanding the game and increasing the fertility of his land."94

While most often this example is cited as a problem of overuse, the tragedy of the Demsetz example can also be seen as one of underuse, or underproduction. The inability to capture a sufficient benefit from an asset may dissuade anyone from incurring costs necessary to make use of that asset. To the extent the asset is an input to the downstream production of something else, then the problem can be characterized as one of underproduction. In the case of inventions, the problem can be viewed as both underuse of the invention and the resulting underproduction of commercial embodiments. ${ }^{95}$

The notion that underuse may arise from a commons has been debated. Posner and Michelman, for example, have argued about whether property rights in crops increase agricultural production. ${ }^{96}$ But while recognizing that the historical record does not strictly provide a resolution to the question, Ellickson has pointed out that "no group in human history has ever treated cultivated crops as an open-access resource that any passerby could harvest." 97

Heller provides another example that he calls "Poach Pond." 98 According to this example, underfishing of a pond may occur if the rule were that any community member could appropriate fish until the moment of consumption because people

supply prompted Labradorian Indians to create exclusive hunting territories).

94. Id. at 356.

95. Such underuse and underproduction may not appear at first glance to be linked to the problem of overuse most often associated with Demsetz. However, as in his example, the underuse of some assets may cause a society to fully deplete its supplies of other assets. See id. at 351-53. In his example, the underuse of animal husbanding and land management resources (skills and labor) led to near exhaustion of animal resources (food and clothing). See id. It was the institution of a right to exclude that provided incentives for individuals to make more use of the one set of resources in order not to waste, and indeed to replenish, the other.

96. The debate is summarized in Robert C. Ellickson, Property in Land, 102 YALE L.J. 1315, 1398-99 (1993) (citing RICHARD A. POSNER, ECONOMIC ANALYSIS OF LAW 32 (4th ed. 1992); Frank I. Michelman, Ethics, Economics, and the Law of Property, in ETHICS, ECONOMICS, AND THE LAW: NOMOS XXIV 25-27 (J. Roland Pennock \& John W. Chapman eds., 1982)).

97. Ellickson, supra note 96, at 1399 (citing Martin J. Bailey, Approximate Optimality of Aboriginal Property Rights, 35 J.L. \& ECON. 183, 185 (1992)).

98. Michael A. Heller, The Tragedy of the Anticommons: Property in the Transition from Marx to Markets, 111 HARV. L. REV. 621, 675 (1998) [hereinafter Heller, The Tragedy of the Anticommons]. 
might prefer to wait on shore and poach the catch of others rather than invest in fishing themselves. ${ }^{99}$ Heller provides this example in his important paper on a topic he calls the tragedy of the anticommons. ${ }^{100}$ His thesis is that when too many owners hold rights of exclusion in a resource, the resource is prone to underuse. ${ }^{101}$ Heller's anticommons approach may suggest an analytical problem for patents. The possibility of numerous patents exerting a right to exclude over a single marketable item ${ }^{102}$ certainly evokes an anticommons image, and Heller and Eisenberg have argued that patents on gene fragments in the biotechnology industry, called ESTs, do raise an anticommons problem. ${ }^{103}$

Heller and Eisenberg raise an important warning about the potential problems of anticommons in biological research. It is not clear, however, that such an anticommons problem actually exists. Furthermore, it is not clear that a shift in patent law would be the proper response. ${ }^{104}$ Prescribing methods for avoiding an anticommons tragedy, Heller himself suggests (1) that close-knit groups may develop informal norms to manage the resource effectively or (2) that we can apply the basic teachings of Demsetz ${ }^{105}$ to determine how best to internalize benefits and costs or to concentrate benefits and costs on owners. ${ }^{106}$ As

99. Id.

100. See generally id.

101. See id. at 624 .

102. Often several patents are simultaneously in force around the same commercial item. So-called overlapping, or mutually-blocking, patents are not rare. Consider, for example, a patent on a widget and a subsequent patent on a widget having rollers - assuming that the addition of rollers to widgets was new and nonobvious. If the only commercially-viable version is one having rollers, then both patentees will be able to prevent the making, using, and selling of the commercial product. Because the patent right is only the right to exclude - and confers no affirmative right to use - even the two patentees are unable to make widgets of the rolling variety without permission from each other.

103. See Heller \& Eisenberg, supra note 9, at 699-700; see also Michael A. Heller, The Boundaries of Private Property, 108 YALE L.J. 1163, 1174-75 (1999) [hereinafter Heller, The Boundaries of Private Property].

104. Indeed, Heller \& Eisenberg discuss reach-through technology license agreements as a very pointed non-patent example of behavior that may lead to anticommons. See Heller \& Eisenberg, supra note 9, at 699. They explain that routinely voluntarily contracting into a dynamic web of contract claims on each other's research laboratories may create assets that no one will develop or buy because too many stakeholders exist. Id. Like the cause, the remedy for such a problem may lie entirely in contractual arrangements.

105. See Demsetz, supra note 92 .

106. See Heller, The Tragedy of the Anticommons, supra note 98, at 677-78. 
already discussed, it is precisely the Demsetz analysis that suggested property rights in inventions in the first place.

Heller and Eisenberg may view the anticommons problem as one of underproduction; they may see patents on ESTs causing underproduction of downstream innovations in genetic research. ${ }^{107}$ Yet, as previously stated, both the Demsetz problem and the basic commercialization of inventions problem can also be characterized as ones of underproduction. Absent the right to exclude, too few commercial embodiments will be produced.

Alternatively, Heller and Eisenberg may view the problem as patents on inputs unduly taxing and retarding subsequent development or production of outputs:

The tragedy of the anticommons refers to the more complex obstacles that arise when a user needs access to multiple patented inputs to create a single useful product. Each upstream patent allows its owner to set up another tollbooth on the road to product development, adding to the cost and slowing the pace of downstream biomedical innovation. ${ }^{108}$

It cannot be, however, that patents on inputs generally prevent the production of outputs. Entire industries have come and gone using scores of patented inputs. Every car is made using countless patented parts, fasteners, processes, and subsystems. Even the biological scientist manages to use a variety of patented machines, reagents, and equipment in the ordinary course of research. It does not appear that Heller and Eisenberg would argue that producers of biological innovations should not have to pay the licensing fee for ordinary inputs, including, for example, the intermittent windshield wiper subsystems on the car they drive to the laboratory in the morning.

Heller and Eisenberg may view the problem as one of downstream research occurring before the patentee of some particular input has managed to figure out a way to turn the more basic invention into a commercial form. Even with adequate incentives, the commercialization of a nascent invention may take time. In this sense, the problem facing such commercialization might be viewed as too much demand too soon. Or more precisely, it might be viewed as an insufficient capacity for product development, marketing, packaging, or distribution. However, if the problem is one of insufficient resources, the so-

107. See Heller \& Eisenberg, supra note 9, at 699-700. A downstream innovation is taken to be one that occurs with the benefit of an earlier innovation.

108. Id. at 699 . 
lution would simply be to facilitate the investment of additional resources in the commercialization process. We typically associate investment with the recognition and enforcement of property rights, rather than their abolition. ${ }^{109}$ Furthermore, we typically look to clear and enforceable boundaries in property rights to provide incentives for investment while at the same time giving clearance to non-infringing activities. ${ }^{110}$

It is also possible that Heller and Eisenberg are not simply concerned with the need for multiple patented inputs to make a single output, but rather are concerned that multiple patent rights might overlap to cover different aspects of a single output. Yet, as with the multiple input problem, this problem has not been so grave as to prevent a host of industries from operating successfully. Numerous patents simultaneously cover countless products sold in ordinary markets. One difference that may exist between the bundling of intangible licenses to make a product and the bundling of tangible licensed inputs to make a product is that there may be a more developed market for tangible licensed inputs.

Whereas the bundling of licenses may be more difficult, however, it is not clear that the law today would present such a problem for the facts Heller and Eisenberg present. Heller and Eisenberg raise the problem of patents on multiple ESTs potentially blocking the use of a larger DNA sequence of which they can be a part. ${ }^{111}$ At least as the law currently stands, there is little risk a patent on a small gene fragment would support a judgment of infringement against a larger DNA sequence, such as a substantial portion of an entire gene.

It is important to properly frame the issues facing EST patents. Curiously, the criticism of patents on ESTs is often phrased as lack of "utility." 112 Yet, there can be no outputrestraining effects of a patent on something useless. Consider

109. See, e.g., generally Richard Epstein, A Clear View of the Cathedral: The Dominance of Property Rules, 106 YALE L.J. 2091 (1997).

110. See generally id.

111. See Heller \& Eisenberg, supra note 9, at 699. ESTs are only small fragments of full-length genes. They are usually not useful in making the product that is encoded by the gene and instead are often used as tags, or markers, to identify whether a particular gene is present. Id. Typically, the full-length gene, or a substantial portion of it, is needed to make the product encoded by that gene. For most pieces of DNA, their biological significance is due mostly to the product they encode.

112. See Heller, The Boundaries of Private Property, supra note 103, at 1174-75. 
the awkwardness facing a defendant in an infringement action who argues that despite practicing the claimed invention, which presumably gave rise to the suit, the patent is invalid because the invention lacks utility. ${ }^{113}$

The proper argument for the defendant is that the larger piece of DNA does not infringe the EST claim. If the patentee attempts to argue that the claim to the smaller fragment does cover the fragment within the environment of the larger DNA, then the defendant's proper argument is that the claim is invalid over the prior art or for lack of adequate disclosure. For a patent to be valid, the claimed subject matter must be new, nonobvious, and the patent application must disclose the metes and bounds of the claimed subject matter with physical and chemical detail as well as how to make and use it. ${ }^{114}$ ESTs exist in nature in the company of the other DNA of the genome. Thus, to overcome this prior art, a typical EST claim must be limited to a version of the EST in some specific environment other than its natural one, such as isolated from all other DNA or inserted into an artificially engineered piece of DNA. Also, to satisfy the disclosure requirements, the details of the degree of isolation or of the engineered piece of DNA must also be provided. To put it another way, a patent claim directed to a gene fragment like an EST cannot be construed to cover larger DNA sequences like a substantial portion of an entire gene without being held invalid over the prior art or invalid for inadequate disclosure. ${ }^{115}$ More simply, a patent on an EST will not preclude the use of an entire gene.

113. As I have argued in other work, it is not even clear that the patent system needs a separate utility requirement. See CHISUM ET AL., supra note 2, at 744-45. There is no harm, and may be some benefit, to granting a patent on a useless invention. A patent on a purportedly useless invention that has many infringers must cover an invention that really is quite useful after all. If the invention really is useless, then no one will want to practice it. As a result, a useless patent does not prevent anyone from doing what he or she would like to do-a useless patent will never be infringed. A useless patent can even have benefits. If the lack of utility is absolute, then the patent teaches others what not to do. If the lack of utility is really just a lack of some practical application, then the patent has still contributed to the public storehouse of basic knowledge. Id. Furthermore, the commercialization view shows why the patent will actually help by providing incentives for coordinated efforts to develop such practical applications.

114. See infra notes 170-71 and accompanying text.

115. See S. Leslie Misrock \& Stephen S. Rabinowitz, The Inventor's Gamble: Written Description and Prophetic Claiming of Biotechnology Inventions, in CHISUM ET AL., supra note 2, at 331. 
Nevertheless, a patent on an EST should allow the patentee to exclude use of that particular EST in isolation or in an engineered construct. This raises an important concern elucidated in an earlier work by Eisenberg in which she suggests that in science, organized skepticism, or the need to scrutinize scientific claims, requires that we permit under patent law the use of a patented invention simply to verify scientific claims by the patentee. ${ }^{116}$ To the extent that the anticommons tragedy does operate, its impact would be particularly pernicious where the need to use is motivated by the mere need for scientific verification. Heller's first proposed solution to the potential tragedy may provide complete relief in this case. Heller suggests that close-knit groups may develop informal norms to manage an anticommons resource effectively. ${ }^{117}$ Federal granting organizations or state licensing boards could require researchers in the basic sciences to grant limited nonexclusive in personam licenses in all inventions to all colleagues, but limited to use in verification only. ${ }^{118}$ Alternatively, collectiverights groups could be organized, like the artists-rights groups ASCAP and BMI in the copyright context, in order to facilitate broad based licenses for a variety of uses across the research sector, thereby assuaging any remaining anticommons concerns. ${ }^{119}$

116. See Rebecca S. Eisenberg, Patents and the Progress of Science: Exclusive Rights and Experimental Use, 56 U. CHI. L. REV. 1017, 1078 (1989).

117. Heller, The Tragedy of the Anticommons, supra note 98, at 677-78.

118. See Joseph M. Reisman, Physicians and Surgeons as Inventors: Reconciling Medical Process Patents and Medical Ethics, 10 HIGH TECH. L.J. 355, 397-98 (1995). In the context of such a verification use, the defendant might even mount an implied license or estoppel defense based on the industry custom and affirmative statements by the patentee asserting scientific truth. Alternatively, the patentee may rationally elect to encourage multiple verifiers - and even challengers - to endeavor to repeat or use his patented work in order to gain additional scientific kudos in the form of citations. JEROME R. RAVETZ, SCIENTIFIC KNOWLEDGE AND ITS SOCIAL PROBLEMS 245 (2d ed. 1996) (noting that scientists throughout time have treated reports of a scientist's work, such as through journal publication, and citation thereto, as valuable currencies in the market for scientific kudos, and reviewing countless ingenious methods scientists have developed for staking out, defending, and even pirating these assets). Such reliance on citation analysis as a measure of $\mathrm{ku}$ dos is not limited to science and indeed is a topic of great interest to communities in other disciplines, such as law. See, e.g., Symposium, Trends in Legal Citations and Scholarship, 71 CHI.-KENT L. REV. 742, 746 (1996).

119. See Reisman, supra note 118, at 400-01. The suggestion of licenses here may raise some concerns about the ability of academic science to fund such licenses. Although funding is an important issue, it is distinct from the issue of whether patents should be available in science. Moreover, the exis- 
Even if relief from anticommons concerns were not complete in the field of biological sciences, the need for commercialization incentives in this industry is uncommonly strong. Costs of commercialization in the biotechnology industry are exceptionally high-it is estimated to take over ten years and several hundred million dollars to bring a single drug to market. ${ }^{20}$ Risks of commercialization in the biotechnology industry are also exceptionally high-only a minute fraction of all compounds that reach clinical trials successfully complete trials and make it all of the way to market. ${ }^{121}$ Moreover, these costs

tence of commercial markets for countless scientific instruments, reagents, and other inputs that are covered by patents demonstrates that the patents are not incompatible with basic science.

120. Exact numbers vary among estimates. See, e.g., STANDARD \& PoOR's, INDUSTRY SURVEYS: BIOTECHNOLOGY 16-17 (Aug. 28, 1997) (“[M]ost new products cost between $\$ 200$ million and $\$ 350$ million to fully develop.”); Joseph A. DiMasi, Cost of Innovation in the Pharmaceutical Industry, 10 J. HEALTH ECON. 107, 125-26 (1991) (estimating an average of twelve years and \$231 million cost for drug research and development); Veronica Henry, Problems with Pharmaceutical Regulation in the United States: Drug Lag and Orphan Drugs, 14 J. LEGAL MED. 617, 617 (1993) (reporting that it costs "approximately $\$ 231$ million and takes approximately ten to twelve years to develop a new drug in the United States"); J. Casey McGlynn \& Grant Heidrich, Biotech Financing Remains a Tough Row to Hoe, 13 BIO/TECH. 638, 639 (1995) (estimating biotechnology research and development at over $\$ 200$ million per product); George Anders, Vital Statistic: Disputed Cost of Creating a Drug, WALL ST. J., Nov. 9, 1993, at B1, B5 (citing an Office of Technology Assessment report that the cost of bringing a new drug to market is $\$ 194$ million after accounting for tax deductions for research and development); Geoffrey Carr, A Survey of the Pharmaceutical Industry: The Alchemists, ECONOMIST, Feb. 21, 1998, at 4 of insert (reporting estimate of $\$ 300$ million to develop a new drug); Shawn Tully, You'll Never Guess Who Really Makes ..., FoRTUNE, Oct. 3, 1994, at 124, 128 ("Bringing a drug to market takes about twelve years."); Interview with Alan Walton, BIOVENTURE VIEW, Jan. 1, 1998, available in 1998 WL 9219211 ("On average, it takes a new drug 6.1 years in discovery, 6.9 years in clinical development, and 2.3 years waiting for FDA review before approval."). Furthermore, few of the drugs that actually reach the market ever recover the costs of research and development. H.G. Grabowski \& J.M. Vernon, A New Look at the Return and Risks to Pharmaceutical R\&D, 36 MANAGEMENT SCI. 804, 804-821 (1990) (reporting that for the period of 1980-1984, only three out of ten drugs that are brought to market cover development costs after taxes and that $20 \%$ of the products with the highest revenues generated $70 \%$ of the profits); F.M. Scherer, Pricing, Profits, and Technological Progress in the Pharmaceutical Industry, 7 J. ECON. PERSP. 97, 106 (1993) (estimating that $55 \%$ of industry profits came from the top ten drugs).

121. Richard G. Halliday et al., R\&D Philosophy and Management in the World's Leading Pharmaceutical Companies, 2 J. PHARMACEUTICAL MED. 139, 139-54 (1992) (reporting that only one out of five thousand compounds synthesized during clinical trials eventually reached the market); Henry, supra note 120, at 617 ("For every 10,000 drug candidates created in the lab only 1000 
and risks are unique to the first mover because marginal cost in this industry is also uncommonly low when compared to initial commercialization costs. ${ }^{122}$ According to the commercialization view offered in this Article, it is precisely this combination of high initial commercialization costs and risks facing the first mover and low marginal costs facing a second mover that makes the biotechnology industry a particularly strong candidate for patent protection. In fact, since the changes in applicable patent law beginning around 1980 that are the focus of patent critics, such as the availability of patent protection for living organisms and gene fragments, ${ }^{123}$ the U.S. biotechnology community has enjoyed particularly rapid and large advances in technology and overall prosperity, ${ }^{124}$ especially compared with the biotechnology communities of other countries that did

compounds will be tested in animals to reveal their pharmacological and toxicological characteristics. Of those 1000 compounds, only one will end up on the pharmacist's shelf. Only one in five new compounds tested in humans is likely to reach the market." (citing Williams \& Copelan, New Drugs for 1993, The CONSUltant PHARMACIST, Mar. 1993, at 208)); Brian H. Vickery, Costs of Research and Patent Considerations, 8 J. ANDROLOGY S-27, S-27 (1987) (calculating that the "overall probability of a . . newly synthesized compound reaching the marketplace reaches the vanishingly small figure of less than 1:12,000 $(0.008 \%)$ ").

122. See, e.g., William D. Noonan, Patenting Medical Technology, $11 \mathrm{~J}$. LEG. MED. 263, 264 (1990) (describing biological inventions as particularly susceptible to piracy because they exhibit high costs to develop but relatively low costs to replicate). Indeed, the relatively low marginal cost in the field of biotechnology is recognized generally, including by the proponents of alternatives to the patent system who target this feature as a reason to avoid patents. See supra notes 10-11. The proponents of alternatives to the patent system rely on this fact of low marginal cost as a reason to avoid property rights because they assume the low marginal cost will be associated with monopoly effects. Yet, as discussed infra in Part II.B, the existence of substitutes will likely prevent patents from having monopoly characteristics, and the ability to price discriminate will likely prevent any patents that do exhibit monopoly characteristics from causing a restriction in output and the commensurate dead-weight loss. Moreover, as discussed infra in the text accompanying notes 218-19, this low marginal cost in the face of large average cost is exactly what makes a compelling need for the commercialization incentives that patents provide.

123. See, e.g., Heller \& Eisenberg, supra note 9, at 699 (criticizing the use of patents on living organisms and gene fragments since the 1980 landmark Supreme Court decision in Diamond v. Chakrabarty, 447 U.S. 303 (1980), which held that living organisms are not per se unpatentable).

124. See generally OFFICE OF TECHNOLOGY Assessment, U.S. CONGRESS, BIOTECHNOLOGY IN A GLOBAL ECONOMY 1-33 (1991) (reviewing changes in the "new biotechnology," which refers to the industrial use of recombinant DNA, cell fusion, and bioprocessing techniques that did not come into regular use until around 1980 or thereafter). 
not readily adopt such changes in applicable patent law as quickly as the United States, if at all. ${ }^{125}$

Furthermore, the large risks of commercialization in the biotechnology industry also provide a particularly strong incentive for patentees in this industry to license broadly as a method for reducing risk. Licensing to hedge risk makes sense because once a firm becomes competent in pursuing one avenue of development, the firm may have difficulty keeping track of other potential avenues. ${ }^{126}$ Indeed, the use of joint ventures and other licensing strategies to reduce commercialization risk in the biotechnology industry is well recognized. ${ }^{127}$

Therefore, rather than becoming clogged, social ordering and bargaining around inventions will operate better if inventions are subject to the property right of a patent. Without the property right acting to concentrate benefits and costs on owners, too few individuals will invest in making use of inventions to bring them to commercial fruition. The popular foil raised against property rights in inventions is that they will unduly tax or retard use in subsequent scientific endeavors. As explored above, however, the concerns raised by such a foil are illusory. The existence of commercial markets for countless scientific inputs that are covered by patents demonstrates that the patent right to exclude does not necessarily prevent scientists from getting access to and using inputs for scientific research. In addition, at least for the example of patents on ESTs, patent law's validity rules operate to prevent patents on many such basic inventions from reaching much of the downstream research as well as most commercial products. Furthermore, the relatively small size of the academic science community suggests that informal norms may evolve to man-

125. See generally Iain Cockburn et al., Pharmaceuticals and Biotechnology, in U.S. INDUSTRY IN 2000: STUDIES IN COMPETITIVE PERFORMANCE 363, 389-92 (David C. Mowery ed., 1999), available at http://www.nap.edu/open book/0309061792/html/363.html (reviewing and explaining reasons for the relative performance of the United States biotechnology industry).

126. See Robert P. Merges \& Richard R. Nelson, On the Complex Economics of Patent Scope, 90 COLUM. L. REV. 839, 873 (1990) (discussing empirical explorations and citing R. NELSON \& S. WINTER, AN EVOLUTIONARY THEORY OF ECONOMIC CHANGE 389 (1982)); see also Kenneth J. Arrow, Economic Welfare and the Allocation of Resources for Invention, in THE RATE AND DIRECTION OF INVENTIVE ACTIVITY II: ECONOMIC AND SOCIAL FACTORS 609, 618-19 (1962) (noting the importance of multiple avenues of research stemming from a single item of information where the particular utility of that information is uncertain).

127. See, e.g., Carr, supra note 120, at 5 of insert. 
age any anticommons concerns that do exist. Even if relief from anticommons concerns were not complete, however, the need for commercialization incentives in this industry is uncommonly strong in the field of biological sciences.

Although the right to exclude does not appear to raise undue concerns specific to academic science, a more general concern levied against patents relates to the power over price that may be conferred by such a right to exclude. Power over price is generally considered to create a dead-weight loss for society. ${ }^{128}$ As described in more detail in the following section, the ability for the patentee to engage in price discrimination may avoid such dead-weight loss.

\section{B. Price Discrimination to Avoid Dead-Weight Loss}

The creation of a property right in inventions is also consistent with another basic work by Demsetz in which he demonstrated that (1) private producers can produce public goods efficiently given the ability to exclude nonpurchasers and (2) price discrimination is consistent with competitive equilibrium for such public goods. ${ }^{129}$ Inventions and their commercialization express prototypical attributes of public goods.

Public goods have two characteristics: they are nonrival and nonexclusive. A good is nonrival if consumption by one person does not leave any less of the good to be consumed by others. ${ }^{130}$ In microeconomic terms, a good is nonrival if for any given level of production, the marginal cost of providing it to an additional consumer is zero. A good is nonexclusive if people cannot be excluded from consuming it. In addition to information, national defense, television signals, and police protection are generally considered to be further examples of public goods. The two distinctive features of public goods-nonrival and nonexclusive-suggest that public goods will tend to be underproduced or not produced at all.

Inventions and their commercialization are nonrival in that their use by one person does not leave any less to be used

128. Dead-weight loss represents a net decrease in societal wealth. For a basic explanation of dead-weight loss, see supra note 22 .

129. Harold Demsetz, The Private Production of Public Goods, 13 J.L. \& ECON. 293 (1970).

130. Recall Thomas Jefferson's letter to Isaac McPherson, wherein Jefferson wrote that "[h]e who receives an idea from me, receives instruction himself without lessening mine; as he who lights his taper at mine, receives light without darkening me." Letter from Thomas Jefferson, supra note 2, at 1291. 
by another. This nonrival nature of inventions is tied very closely to one of the central concerns expressed by critics of the patent system. After invention, the marginal cost of production for each subsequent use of the invention is very low, even approximating zero in most cases. Yet the patentee must charge at least average cost-which includes fixed costs of inventing and commercializing-in order to break even. The right to exclude gives the patentee potential power over price, permitting him to charge above marginal cost and thereby potentially creating dead-weight loss. ${ }^{131}$ It is the elimination of this deadweight loss that motivates the criticisms of the patent system discussed earlier. ${ }^{132}$

Absent patent protection, inventions and their commercialization are also nonexclusive. To be sure, self-help mechanisms may operate to give some level of exclusivity to some inventions. Each of these self-help mechanisms has limitations. For example, secrecy is not feasible for some inventions, such as those easily reverse-engineered. In addition, breach of secrecy can benefit the entire world of competitors, including those not complicit in the breach and therefore whose use would not be actionable. Similarly, limiting contract provisions may operate to give some cause of action against contracting parties but will only reach those with privity of contract. Moreover, neither secrecy nor contract limitations will operate against independent creation.

The patent system operates by creating a legal form of exclusivity. Importantly, as Demsetz makes clear, the deadweight loss ordinarily associated with exclusivity can be avoided by price discrimination. ${ }^{133}$ One method of price discrimination suggested by Demsetz is the tying of a public good with a private good that is excludable. ${ }^{134}$ Indeed, Demsetz shows that private producers of public goods may simply create this type of linking themselves as a method for funding the

131. The creation of dead-weight loss from pricing above marginal costs can best be seen in the context of monopoly pricing. For a basic explanation of dead-weight loss, see supra note 22 . A more thorough, but easily readable description can be found in PINDYCK \& RUBINFELD, supra note 56, at 333-52. The reader with a taste for higher math and multivariate calculus may prefer the teachings in BRIAN R. BINGER \& ELIZABETH HOFFMAN, MICROECONOMICS WITH CALCULUS 375-85 (1988), or HAL R. VARIAN, MICROECONOMIC ANALYSIS 79-95 (1984).

132. See supra text accompanying notes 27-46.

133. See Demsetz, supra note 129 , at $310-12$.

134. Id. at 306. 
public good's production. ${ }^{135}$ For example, Demsetz explains two types of tie-ins for the provision of radio and television broadcasting: a tie to advertisers who want viewer attention and will pay for commercial air time or a tie to set manufacturers who would want to support popular shows to foster demand for sets. ${ }^{136}$ But such ties are not always possible under given market and technological conditions absent the legal right to exclude afforded by a patent.

It may seem that a governmentally created patent right would be antithetical to Demsetz in view of his conclusion that because such tie-ins may be available mechanisms by which the private sector can produce public goods, it is imprudent to look first to government for public good production. ${ }^{137}$ He does recognize, however, that such a tie-in mechanism may not lend itself to the efficient production of some public goods. Indeed, even his suggested tie-in scheme may face a free rider problem between the two sources of funding. Set manufacturers may underrepresent their interest in having good shows knowing that the advertisers will have a strong interest in keeping something on the air that holds the attention of the audience. Set producers may not even care whether audiences prefer programs, informative advertisements, or amusing advertisements, as long as they want to buy sets.

The patent system offers Demsetz a minimal form of government intervention for facilitating tie-ins, at least less than would be required for government production and commercialization of inventions, which were the target of his criticism. ${ }^{138}$ Under the patent system, the potential for tie-ins comes from the patentee's right to exclude for direct infringement as well as contributory and induced infringement. The creation of such a legal ability to tie-in would operate to enable tie-ins where technological and economic factors alone might make ties difficult, and would generally broaden the range of tie-ins possible. Thus, a patent system that facilitated appropriate tie-ins would theoretically operate to allow private commercialization of inventions without the creation of dead-weight loss.

Although perfect price discrimination is impossible, it may also not be necessary because the extent of a patentee's power

135. See id.

136. Id.

137. See id.

138. See id. 
over price may be otherwise limited. More specifically, patents may not give a great deal of monopoly or even market power. Patents often do not define markets. ${ }^{139}$ Markets order themselves around consumer demand-producers sell what consumers will buy. In general, consumers buy to satisfy their needs or desires. In the context of a particular consumer problem, like mouse infestation, for example, consumers need or want solutions, and producers sell these solutions, perhaps in the form of mouse traps or cats. A patentee can exclude others from making, using, selling, or offering for sale a particular invention. In a market for solutions, a patentee can prevent others from selling a certain solution, though not all solutions, to a given problem. For example, people will buy better mousetraps only if they cost less than cats, accounting for all costs and benefits such as cat food and companionship.

As Kitch has pointed out, patented inventions also face the competitive pressures of time. ${ }^{140}$ Early in life, the patented invention faces competition from the very technologies it has rendered obsolete. For example, older technologies may be somewhat less effective but still be cheaper, in price or total cost of use. Similarly, changes in related industries can make the formerly obsolete technologically or economically superior to

139. For precisely this reason, Justice Clark writing for the Supreme Court noted,

To establish monopolization or attempt to monopolize ... it would then be necessary to appraise the exclusionary power of the ... patent claim in terms of the relevant market for the product involved. Without a definition of that market there is no way to measure [the patentee's] ability to lessen or destroy competition. It may be that the [patented] device... does not comprise a relevant market. There may be effective substitutes for the device which do not infringe the patent.

Walker Process Equip., Inc. v. Food Mach. \& Chem. Corp., 382 U.S. 172, 177-

78 (1965). Dam has similarly noted,

Indeed, it became conventional to say that a patent is a monopoly. Nonetheless, it is readily apparent that the right to exclude another from "manufacture, use, and sale" may give no significant market power, even when the patent covers a product that is sold in the market. Indeed, without the benefit of empirical research, it is entirely plausible to conclude that in the great bulk of instances no significant market power is granted. We must bear in mind that leading companies may obtain 1,000 or more patents in a single year, and yet many such firms are unlikely ever to obtain even a single monopoly in any market.

Kenneth W. Dam, The Economic Underpinnings of Patent Law, 23 J. LEGAL STUD. 247, 249-50 (1994) (citations omitted).

140. See Edmund W. Kitch, Patents: Monopolies or Property Rights?, 8 RES. L. \& ECON. 31, 31 (1986). 
the new technology. Later in life, the patented invention may face competition from even newer inventions. Most importantly, patent term is limited to about seventeen years on average, ${ }^{141}$ and upon expiration, the patentee will face competition over the invention itself.

To be sure, under the right circumstances, the case of a patented drug may provide an example of a market having a sufficient barrier to entry to be a monopoly. The patent term and the state of the evolving art would have to be such that there exists a certain class of patients having such an acute illness that they are unable to wait for the development of alternative noninfringing solutions or for patent expiration. In this case, the limited market at this time and for these patients is a monopoly. Price discrimination may be a particularly important tool for eliminating dead-weight loss in such markets. ${ }^{142}$ Moreover, as Demsetz recognized, any remaining dead-weight loss in the static analysis may still be a worthwhile sacrifice in return for the gains from enhanced output of invention commercialization in the dynamic analysis. ${ }^{143}$

The dead-weight loss potentially caused by a patent right to exclude may loom ominously before commentators on the patent system, but its menace is merely phantasmal. Concerns about dead-weight loss do not provide a proper motivation for seeking alternatives to the system. Most patents fail to give any significant market power, especially not monopoly power. Even if a perfect monopoly were associated with a patented

141. See infra note 164 and accompanying text.

142. The ability to charge each patient exactly her reserve price, above which she would not pay, would provide the seller with a strong financial incentive to find and sell to each patient. If price discrimination is available, the seller has a strong financial motivation to increase output to the same levels as under a competitive market. To be sure, such price discrimination requires the ability to prevent arbitrage among patients, such as through enforceable contract terms against resale. In addition, consumer subsidies may provide another solution. See Lichtman, supra note 91, at 126-30.

143. See Harold Demsetz, Information and Efficiency: Another Viewpoint, 12 J.L. \& ECON. 1, 1 (1969) (critiquing the so-called nirvana approach in favor of a comparative institution approach). Demsetz notes that Arrow's indivisibility problem may be handled best by a private property system that reduces the cost of contracting and raises the cost of free loading while simultaneously providing incentives for investment. See id. at 14 (critiquing Arrow, supra note 126, at 609-25). Even critics of the use of price discrimination when unconnected to intellectual property rights recognize its important beneficial impact when used in conjunction with intellectual property rights. See Wendy J. Gordon, Intellectual Property as Price Discrimination: Implications for Contract, 73 CHI.-KENT L. REV. 1367, 1375 (1998). 
product, the patent system gives the patentee a strong financial incentive to avoid the dead-weight loss typically associated with monopolies. The ability to price discriminate gives the patentee incentive to elect not to restrict output by allowing the patentee to profit for each additional unit of output sold, up to the same total level of output that would be sold in a competitive market.

\section{Property Rules to Avoid Underuse}

Simply deciding that patents should be property rights does not necessarily settle the question of whether they should be enforced as property rules rather than liability rules. ${ }^{144}$ An entitlement enjoys the protection of a property rule if the law condones its surrender only through voluntary exchange. ${ }^{145}$ The holder of such an entitlement is allowed to enjoin infringement. ${ }^{146}$ An entitlement has the lesser protection of a liability rule if it can be lost lawfully to anyone willing to pay some court-determined compensation. ${ }^{147}$ The holder of such an entitlement is only entitled to damages caused by infringement. ${ }^{148}$

A recent article by Ayres and Klemperer essentially advocates a liability rule for patents by suggesting that, like a system of compulsory licenses, a patent litigation system characterized by uncertainty and delay but increased patent term may provide adequate incentives for patentees while reducing the distortionary effects of an absolute right to exclude. ${ }^{149} \mathrm{Al}-$ though the argument presented by Ayres and Klemperer is insightful, there are several reasons that only property rules are appropriate for patents.

Under the commercialization view of patents, there are a number of parties who want to and must be able to contract over patent rights. For example, complete transferability is important to ensure that commercialization is conducted by the lowest cost provider. Similarly, varying degrees of licensing

144. See Guido Calabresi \& A. Douglas Melamed, Property Rules, Liability Rules, and Inalienability: One View of the Cathedral, 85 HARV. L. REV. 1089, 1092 (1972).

145. See id. at 1105 .

146. See id.

147. See id. at 1105-06.

148. See id.

149. See Ayres \& Klemperer, supra note 8, at 992 (criticizing the crispness of the present patent system). 
must occur to facilitate price discrimination. But the costs of such transactions increase with uncertainty in enforcement. As recognized by Haddock, McChesney, and Speigel, the potential infringements induced by a liability rule will discourage investments in the invention ex ante. ${ }^{150}$ Especially in the case of a large number of potential traders for the asset, the imposition of a liability rule may create a prisoner's dilemma in which each player's dominant strategy is to infringe in order to garner more of the potential gains from exchange for himself. ${ }^{151}$

It is precisely because all of these players will individually want to come together and bargain that the costs of evaluating the commercialization of the invention will be less than those facing an inexperienced decision maker like a court. As recognized by Merges, the fact that private parties have a comparative advantage over courts in valuing patents would trigger the imposition of a property rule rather than a liability rule under the Calabresi and Melamed test. ${ }^{152}$

In the context of the Ayres and Klemperer model, in which each potential infringer is disciplined to not infringe too much now by the threat of damages in the future, the prisoner's dilemma may look more like the typical overproduction problem that plagues a cartel. Each infringer may calculate the impact of his marginal output on price without taking into account the output from other infringers. Such uncoordinated acts of infringement may cause collective profits-those reaped by the patentee directly and through damages awards from infringers-to fall below the total costs of creating and commercializing the invention, resulting in a destruction of wealth. ${ }^{153}$ To put it another way, liability rules can be strategically abused. ${ }^{154}$

150. See David D. Haddock et al., An Ordinary Economic Rationale for EXtraordinary Legal Sanctions, 78 CAL. L. REV. 1, 16-17 (1990).

151. See id. at 17.

152. See Robert P. Merges, Of Property Rules, Coase, and Intellectual Property, 94 COLUM. L. REV. 2655, 2664 (1994) (citing Calabresi \& Melamed, supra note 144). According to Calabresi and Melamed, the inquiry requires a comparison of the relative costs of establishing the value of an initial entitlement. See Calabresi \& Melamed, supra note 144, at 1106-10. A liability rule should be used if a collective, public, or governmental determination would be cheaper than a private evaluation reached by agreement of the parties. A property rule should be used if the private evaluation would be cheaper. See id.

153. As Ayres and Klemperer recognize, if there are fixed costs of entry or exit, or if infringers have higher marginal cost than the patentee, then market entry by infringers will generate extra costs for society. See Ayres \& Klemperer, supra note 8 , at 1015 . In addition, although economic theory teaches 
In theory, there may be some increase in term or geographic scope of the patent sufficient to compensate for this destruction of wealth. ${ }^{155}$ As Ayres and Klemperer recognize, however, the difficulties in implementing such a compensatory device increase with the size of the compensation required. For example, patents of longer term will face increasing chances of losing some or all market power to newer competing technologies. ${ }^{156}$ In addition, though such compensating devices might serve to ensure that the patentees, individually, continue to face adequate incentives, they will not make up for any net decrease in social wealth. ${ }^{157}$ Acts of infringement may therefore actually lead to destruction of value. The model presented by Haddock, McChesney, and Spiegel shows that the imposition of a property rule is therefore required in order to put the defendant back in the place he would have been but for the infringement, leaving him no incentive to attempt the activity in the first place. ${ }^{158}$

Longer term may also create or exacerbate the potential anticommons problems raised by Heller and Eisenberg. ${ }^{159}$ Increased term for each patent substantially increases the likelihood that the manufacturer of a given output will need to assemble larger numbers of tangible licensed patent inputs or intangible patent licenses. In this sense, shorter patent term can be viewed as facilitating contracting by clearing the governmental register of rights claimants more quickly than otherwise. In addition, as may happen with any form of property,

that in a long run equilibrium only the most efficient producers in the most efficient number will remain in the market, during the relatively short time of patent life - seventeen years on average the costs associated with "weedouts" are likely to be significant.

154. See Haddock et al., supra note 150, at 13. Although the Ayres and Klemperer argument does suggest that in some cases a low level of infringement may be optimal, this amount of infringement is already available under the present patent system because of other areas of procedural and substantive law and practice. Concerning procedure, litigation costs may be high enough to prevent the patentee from seeking court intervention against an infringer. Concerning substance, the limitations on liability that are available to a would-be infringer through the use of the corporate form or bankruptcy laws, for example, may encourage acts of infringements that are essentially judgment proof.

155. See Ayres \& Klemperer, supra note 8, at 1015, 1027-28.

156. For a discussion of the competitive pressure of time on a patentee's market power, see supra text accompanying note 140 .

157. See supra text accompanying note 153.

158. See Haddock et al., supra note 150, at 13.

159. See supra text accompanying notes 98-111. 
increasing term will also increase the possibility of fragmentation in ownership of that property itself, which may create an anticommons problem for both stakeholders and third parties, each of whom may be unable to gather permission necessary to realize full value of the asset from all stakeholders. ${ }^{160}$

Indeed, the possibility of fragmented ownership presents a particular problem for patents. The patent right is only a right to exclude, not a right to use. In addition, each co-owner of a patent can decide not to exclude third parties, by giving a partial assignment or license, without accounting to any other coowner. ${ }^{161}$ As a result, an assignment by a co-owner will dissipate the entire value of the patent for all other owners. For this reason, it is well recognized that co-ownership in patents can create a tragedy of the commons. ${ }^{162}$ Thus, the enforcement of the patent right with a liability rule, as compared with a property rule, will not only frustrate the commercialization goals of the system, but the commercialization aspect of the system makes it particularly well suited for a property rule.

The commercialization view of the patent system therefore helps elucidate why the power to restrict output is paradoxically essential to providing incentives for the market to generate output. Rights of exclusion facilitate efforts for the social ordering and bargaining around inventions that are necessary to generate output. Concerns raised by the popular foil against property rights in inventions-that biotechnology patents will unduly tax or retard use in subsequent scientific endeavorsare belied by the existence of commercial markets for countless scientific inputs that are covered by patents. They also pale in comparison to the sharp need for patents in the biotechnology industry. Concerns about dead-weight loss also do not provide a proper motivation for seeking alternatives to the system. Most patents fail to give any significant market power and the patent system's ability to price discriminate actually gives the patentee strong financial incentive to elect not to restrict output, thereby avoiding the dead-weight loss typically associated with monopolies. Indeed, not only are property rights of exclusion advantageous, they must also be enforced by a property rule, and not a liability rule. The use of liability rules would lead to a net increase in social cost and frustrate the very ef-

160. See supra notes $98-103$ and accompanying text.

161. See 35 U.S.C. $§ 262$ (1994).

162. See Robert PATRICK Merges, PATENT LAW AND Policy 1228-36 (2d ed. 1997). 
forts for ordering and bargaining around patents that are necessary to generate output of patented inventions.

Having reviewed how the commercialization view of patents helps elucidate why the system should function better than suggested alternatives, the section that follows explores some of the detailed operations of the system to show how functionality is achieved. The following section also reveals how property rights and commercialization motivated the creation of our current patent system.

\section{COMMERCIALIZATION BY DESIGN}

The modern patent system provides the incentive to commercialize without the creation of dead-weight loss by setting forth crisp and enforceable rules for determining both validity and infringement. The power of the patent derives from the patent's grant of a limited right to exclude. The owner of a patent can prevent anyone from making, using, offering for sale, selling, or importing the patented invention for the entire term of the patent. ${ }^{163}$ Neither innocent copying nor independent origination of a patented invention provides a defense to patent infringement. Although the protection afforded by patents is very strong, it is also short in comparison to the protection available for copyrights and trademarks. In general, patents last for only seventeen years. ${ }^{164}$

In addition, the patentee's ability to conduct price discrimination is based on the ability to sue or elect to license both

163. See 35 U.S.C. $\$ \S 154,271$ (1994). The right to exclude is all that the patent gives. See Bloomer v. McQuewan, 42 U.S. (14 How.) 539, 549 (1852) ("The franchise which the patent grants, consists altogether in the right to exclude every one from making...."). A patent confers no right to use. For a general discussion of patents and the patent grant, see CHISUM ET AL., supra note 2 , at $2-7$, and for a detailed review of the rights and limitations of the patent grant, see id. at 894-1030.

164. All patents arising out of applications that were filed before June 8, 1995 have a patent term that spans seventeen years from the issue date of the patent. Patents arising out of applications that were filed on or after June 8, 1995, have a patent term that begins on the date the patent issues but lasts twenty years measured from the earliest claimed application filing date. See Pub L. No. 103-465, 108 Stat. 4809, 4988-89 (1994). The average term for these more recent applications will remain seventeen years because for most applications, there is an average of three years between filing and issuance. However, if the application claims the benefit of a substantially earlier filing date (to antedate certain prior art, for example), then the patent term may be much shorter. For a brief discussion of the change from a seventeen to twenty year patent term, see CHISUM ET AL., supra note 2, at 898-900. 
direct and indirect infringers and even grant restrictive licenses. The patent laws give causes of action for both inducement of infringement and contributory infringement and expressly allow the patentee to elect to grant a restrictive or unrestrictive license ${ }^{165}$ to a potential infringer without being guilty of patent misuse. ${ }^{166}$ For example, a patentee may provide an expensive patented machine at some low fixed cost, perhaps zero, but charge per use directly or through a counting mechanism such as through the concurrent selling at a markup of some low cost but unique input. ${ }^{167}$

165. An unrestrictive license allows the licensee to practice the invention free from suit for infringement by the patentee. A restrictive license gives less than such unlimited permission, such as by restricting the amount or type of use.

166. Inducement of infringement and contributory infringement are collectively referred to as two forms of indirect infringement because under both causes of action the defendant is accountable as an infringer for acts of infringement by third parties. See 35 U.S.C. $\S 271$ (b) (codifying the cause of action for inducement of infringement); 35 U.S.C. $\$ 271$ (c) (codifying the cause of action for contributory infringement); 35 U.S.C. $\S 271$ (d) (codifying the rule that a patentee may elect to license direct or indirect infringers without committing patent misuse); see also CHISUM ET AL., supra note 2, at 894-1030.

167. Such a "counters" argument was successfully made to Chief Circuit Judge Lurton by Frederick P. Fish (founding partner of the firm Fish, Richardson \& Neave, predecessor to the two firms Fish \& Richardson and Fish $\&$ Neave) in the Button Fastener Case, and ultimately led to the opinion by Justice Lurton (the same man) in the A.B. Dick case, also argued by Fish. See Heaton-Peninsular Button-Fastener Co. v. Eureka Specialty Co., 77 F. 288 (6th Cir. 1896) (the "Button Fastener Case"); Henry v. A.B. Dick Co., 224 U.S. 1 (1912). The "counters" argument offered the unpatented staples sold by the patentee at a substantial profit as convenient proxies used to count the number of infringing uses by purchasers of the patented stapling machine-which was sold by the patentee at or below cost. See Giles S. Rich, The Relation Between Patent Practices and the Anti-Monopoly Laws, 24 J. PAT. OFF. SoC'Y 241, 246-60 (1942) (citing Heaton-Peninsular Button-Fastener Co. v. Eureka Specialty Co., 77 F. 288 (6th Cir. 1896) (opinion by Lurton, C.J.) (the "Button Fastener Case"), and Henry v. A.B. Dick Co., 224 U.S. 1 (1912) (opinion by Lurton, J.)).

Dissenting in Brulotte $v$. Thys from the holding that a patentee engages in misuse if he charges royalties that extend beyond the patent term, Justice Harlan provided a pointed example demonstrating the mutual gains from trade that are available in such a transaction:

At the time when the Thys patent term still has a few years to run, a farmer who has been picking his hops by hand comes into the Thys retail outlet to inquire about the mechanical pickers. The salesman concludes his description of the advantages of the Thys machine with the price tag - $\$ 20,000$. Value to the farmer depends completely on the use he will derive from the machine; he is willing to obligate himself on long credit terms to pay $\$ 10,000$, but unless the machine can substantially outpick his old hand-picking methods, it is worth no more to him. He therefore offers to pay $\$ 2,000$ down, $\$ 400$ annually 
The rules for determining patentability are clear. To be patentable, an invention must be new. ${ }^{168}$ It must also be nonobvious. ${ }^{169}$ In addition, the text, or specification of a patent

for 20 years, and an additional payment during the contract term for any production he can derive from the machine over and above the minimum amount he could pick by hand. Thys accepts, and by doing so, according to the majority, commits a per se misuse of its patent. I cannot believe that this is good law.

Brulotte v. Thys Co., 379 U.S. 29, 38 (1964) (Harlan, J., dissenting). Indeed, Justice Harlan's reasoning demonstrates that the same effect can be achieved if the parties merely re-label the operative term in their contract from "royalty payment" to "financing provision" or if they make the exchange appear to be one in which the patentee is providing some benefit that is in addition to the patent license, such as a service contract. By giving less, the patentee might commit misuse.

Justice Robin Jacob has pointed out that a savvy patentee might achieve the same advantageous result by including a number of successively narrow claims in the initial patent application. For example, the inventor of a paint spray gun might also claim the use of the device to spray paint. It would be much easier for such a patentee to avoid an antitrust tying complaint if he elected to charge for each use of the device. Robin Jacob, Objectionable Narrowness of Claim, in CHISUM ET AL., supra note 2, at 974.

For a general criticism of the doctrine of patent misuse, see Ward S. Bowman, Jr., Misuse of Patents or Misuse of Patent and Antitrust Law? Address Before the Patent, Trademark and Copyright Section of the American Bar Association Meeting (Aug. 14, 1974) (transcript on file with author).

168. 35 U.S.C. $\$ 102$ (1994). A patent claim is invalid for anticipation under $\S 102$ if any single available item of prior art discloses, either expressly or inherently, each and every limitation of the claimed invention in a manner sufficient to enable one skilled in the art to reduce the invention to practice. Thus the famous aphorism: "That which infringes, if later, would anticipate if earlier." Knapp v. Morss, 150 U.S. 221, 228 (1893). For a detailed discussion of the novelty and statutory bar requirements in patent law, see CHISUM ET AL., supra note 2 , at $335-529$.

169. 35 U.S.C. $§ 103$ (1994). The legal test for obviousness was articulated by the Supreme Court in Graham v. John Deere Co., 383 U.S. 1 (1966):

Under $\S 103$, the scope and content of the prior art are to be determined; differences between the prior art and the claims at issue are to be ascertained; and the level of ordinary skill in the pertinent art resolved. Against this background, the obviousness or nonobviousness of the subject matter is determined. Such secondary considerations as commercial success, long felt but unsolved needs, failure of others, etc., might be utilized to give light to the circumstances surrounding the origin of the subject matter sought to be patented. As indicia of obviousness or nonobviousness, these inquiries may have relevancy.

Id. at 17-18. The relevant inquiry is whether the prior art as a whole suggested the claimed invention, and indicated to a person having ordinary skill in the art a reasonable expectation of success in achieving the claimed invention. Obviousness is like anticipation but instead of all elements of the claim existing in a single item of prior art, the elements may be spread among two or more pieces of prior art as long as they also provide that a motivation or suggestion to be combined along with a reasonable expectation of success. See In re Dow Chem. Co. 837 F.2d 469, 473 (Fed. Cir. 1988). For a detailed discus- 
must (1) include a written description of the invention, (2) instruct as to the construction and use of the invention, (3) divulge what the inventor considers the best way to use the invention, and (4) conclude with one or more claims particularly pointing out and distinctly claiming the process or thing patented. ${ }^{170}$ The scope of the patent's right to exclude is set by the claim (or claims). ${ }^{171}$

The present crispness did not always exist for the patent system. Before the 1952 Patent Act, codified as Title 35 of the United States Code, the patent system was much different. On April 29, 1938, addressing a joint session of Congress, President Roosevelt requested a thorough study of what he described as a "concentration of economic power." 172 Congress responded by creating the Temporary National Economic Committee ("TNEC"), the purpose of which was to study "monopoly and the concentration of economic power ... with a view to determining ... [inter alia] the effect of existing ... patent, and other Government policies upon competition, price levels, unemployment, profits and consumption."173

What followed was the gradual but systematic erosion of patent rights throughout the courts. By the late 1940s courts were on average applying a substantially more stringent, but difficult to discern, test for "invention" when deciding issues of validity. ${ }^{174}$ The nature of the test was aptly described in the

sion of the nonobviousness requirement, see CHISUM ET AL., supra note 2, at 530-728. For an excellent exposition of the history of the requirement, see George M. Sirilla, 35 U.S.C. $\&$ 103: From Hotchkiss to Hand to Rich, The Obvious Patent Law Hall-of-Famers, 32 J. MARSHALL L. REV. 437, 458-87 (1999).

170. 35 U.S.C. $§ 112$ (1994). For a detailed review of the disclosure requirements, see CHISUM ET AL., supra note 2 , at $155-334$.

171. As Judge Rich stated,

The U.S. is strictly an examination country and the main purpose of the examination, to which every application is subjected, is to try to make sure that what each claim defines is patentable. To coin a phrase, the name of the game is the claim ... [and] the function of claims is to enable everyone to know, without going through a lawsuit, what infringes the patent and what does not.

Hilton Davis Chem. Co. v. Warner Jenkinson Co., 62 F.3d 1512, 1539 (Fed. Cir. 1995) (quoting Giles Rich, The Extent of the Protection and Interpretation of Claims-American Prospectives, 21 INT'L REV. INDUS. PROP. \& COPYRIGHT L. $497,499,501(1990))$.

172. S. DoC. No. $75-173$, at 7 (1938).

173. S.J. Res. 300, 75th Cong. § 2 (1938).

174. See Giles S. Rich, Congressional Intent-or, Who Wrote the Patent Act of 1952?, reprinted in NONOBVIOUSNESS - THE ULTIMATE CONDITION OF PATENTABILITY 1:1, 1:3 (John F. Witherspoon ed., 1980) [hereinafter 
remarks of Justice Jackson in a 1949 dissent: "[T]he only patent that is valid is one which this court has not been able to get its hands on."175 In addition, the Supreme Court had virtually eliminated the doctrine of contributory infringement through aggressive use of antitrust principles and the related doctrine of patent misuse. ${ }^{176}$ Earlier, the doctrine of contributory infringement, and the corresponding ability of patentees to elect to license potential contributory infringers, were available tools for facilitating the type of tie-in price discrimination suggested by Demsetz. ${ }^{177}$

Heady with success in implementing the Lanham Trademark Act a few years earlier, in 1948, the New York Patent Law Association enlisted Giles Rich to draft for introduction in Congress a bill ${ }^{178}$ to revive contributory infringement and two other bills ${ }^{179}$ to establish a more definite test for what constitutes an "invention." 180 Legislative efforts continued into subsequent Congresses, leading to the formation of a National Coordinating Committee and a two-man Drafting Committee, including Rich, and producing extensive congressional testimony from representatives of diverse groups, again including Rich, as representative of the Bar. ${ }^{181}$ The result was the 1952 Act, which substantially remains as the controlling patent law today. ${ }^{182}$ As the Supreme Court expressly recognized almost

NONOBVIOUSNESS].

175. Jurgensen v. Ostby \& Barton Co., 335 U.S. 560, 572 (1949) (Jackson, J., dissenting).

176. See NONOBVIOUSNESS, supra note 174 , at 1:3. The doctrines of inducement of infringement and contributory infringement hold a defendant accountable as an infringer for acts of infringement by third parties. See supra note 166 . By the late $1940 \mathrm{~s}$, the court had effectively eliminated contributory infringement by holding that such suits improperly extended the patent beyond the scope of the claims, thereby constituting misuse of the patent. See NonOBVIOUSNESS, supra note 174 , at 1:3 (citing Mercoid Corp. v. MidContinent Inv. Co., 320 U.S. 661 (1944); Mercoid Corp. v. Minneapolis Honeywell Regulator Co., 320 U.S. 680 (1944)).

177. See supra text accompanying notes 129-38.

178. H.R. 5988, 80th Cong. (1948).

179. H.R. 4061, 80th Cong. (1948); H.R. 5248, 80th Cong. (1948).

180. See NONOBVIOUSNESS, supra note 174 , at 1:3.

181. See id. at 1:3-1:10.

182. A great deal has been written about the history of the 1952 Patent Act. An extensive discussion of the history and impact of the Act can be found in Dawson Chem. v. Rohm \& Haas, 448 U.S. 176 (1980), which found no misuse where the holder of a patent on the method of using a chemical as a herbicide charges customers above market price for the chemical itself and sues competing chemical company for contributory infringement. See id. at 223; see 
thirty years later in an opinion quoting extensively from the Rich testimony, § 271 of the Act revived contributory infringement through its inclusion of express provisions for contributory infringement and inducement of infringement and of express statements about what shall not constitute misuse. ${ }^{183}$

Especially when seen in such context, the plain wording of the 1952 Act shows a clear shift towards a patent system marked by more certain and effective patent rights. Indeed, the importance of commercialization to the members of the Patent Bar in general, and to Giles Rich, is clearly evidenced by other writings from the time. As part of a competition sponsored by the Linthicum Foundation and chaired by Dean Wigmore, Rich wrote what became a five-part series of articles on the relationship between patent and antitrust laws. ${ }^{184}$ In this series, Rich expressly set forth a commercialization theory of the patent system. ${ }^{185}$ In doing so, he provided several detailed examples of the underuse problem associated with the lack of property rights. ${ }^{186}$ It is immediately recognizable that these problems of underuse are caused by the inability to concentrate benefits and costs on owners, as described almost thirty years later by Demsetz. ${ }^{187}$

also NONOBVIOUSNESS, supra note 174 . West published the Congressional Committee Reports on the 1952 Patent Act in its original annotated version of Title 35. The legislative history of the 1952 Patent Act is republished along with the original commentary by Pasquale "Pat" Federico, the Patent Office's liaison to the Drafting Committee and representative at legislative hearings on the Act, in 75 J. PAT. OFF. SOC'Y 157 (1993).

183. See 35 U.S.C. $§ 271$ (b)-(d); see also Dawson Chem., 448 U.S. at 206-07 (quoting extensively from and basing decision upon testimony of Giles Rich). For a discussion focused on the history, architecture, and operation of $\S 271$, see Giles S. Rich, Infringement Under Section 271 of the Patent Act of 1952, 35 J. PAT. OFF. SOC'Y 476 (1953), and Giles S. Rich, Recollections of Writing 35 USC 271, Address at the John Marshall Conference (1981).

184. See Giles S. Rich, The Relation Between Patent Practices and the AntiMonopoly Laws (pts. 1-5), 24 J. PAT. OFF. SoC'Y 85, 159, 241, 328, 422 (1942) [hereinafter Rich, The Relation Between Practices and the Anti-Monopoly Laws]. Rich tells the story of the competition in his famous acceptance speech for the Kettering Award, Giles S. Rich, The Vague Concept of "Invention" as Replaced by Sec. 103 of the 1952 Patent Act, 46 J. PAT. OFF. SOC'Y 855 (1964) [hereinafter Rich, The Vague Concept of "Invention"], which provided the framework for the test of nonobviousness adopted by the Supreme Court in Graham v. John Deere Co., 383 U.S. 1, 3 (1966).

185. See generally Rich, The Relation Between Practices and the AntiMonopoly Laws, supra note 184.

186. See id.

187. See supra text accompanying notes 92-95. 
Rich began his discussion of patent theory by marginalizing theories of the patent system based on rewards as incentives to invent or disclose because they both focus "primarily with reference to the 'inventor' as though he were the principal character in this economic drama. We think this is a great mistake. He may be an essential party but the emphasis should be placed elsewhere."188

Instead, Rich suggested that focus should be placed on a third theory:

The third aspect of inducement is by far the greatest in practical importance. It applies to the inventor but not solely to him, unless he is his own capitalist.... It might be called the inducement to risk an attempt to commercialize the invention. It is the "business" aspect of the matter which is responsible for the actual delivery of the invention into the hands of the public. ${ }^{189}$

Rich proceeded to quote at length from an editorial in Business Week that described the costs and risks of commercialization. 190 He continued by quoting from another editorial in Business Week that described a new plastic made from sawdust developed by the United States Forest Service. The plastic made from sawdust was licensed freely and nonexclusively for the use of all, and as a result, it was not further developed. ${ }^{191}$

He then cited a more pointed example from the health care industry of the inventor of a new wheelchair, who, thinking to give it to the world for free, did not patent it: "The result was that no manufacturer dared risk undertaking its manufacture. Each knew that if it succeeded, competitors would spring up and rob him of most or all of his profits, while, on the other hand, it might fail." 192 Rich then quoted from the Patent Commissioner's testimony before the TNEC which asserted: "I think I can present to you indisputable evidence that speculative capital will not back new inventions without the patent protection. And in the final analysis this is the crux and the most important thing in the whole patent question."193

188. Rich, The Relation Between Patent Practices and the Anti-Monopoly Laws, supra note 184, at 175 .

189. Id. at 177 (emphasis added).

190. See id. at 178 (quoting Editorial, Bus. WK., Mar. 23, 1940, at 55).

191. See id. at 178-79 (quoting Editorial, Bus. WK., Dec. 23, 1939, at 29).

192. Id. at 179 (quoting Forkosch, The Economics of American Patent Law, Contemp. Law. Pamph., Ser. 4, No. 2, at 21 (citing ElEMENTARY PRINCIPLES OF ECONOMICS 331 (1913))).

193. Id. at 180 (quoting TNEC Hearings, pt. 3, 857-58 (1939) (statement of Conrad P. Coe, Commissioner of Patents), reprinted in 21 J. PAT. OFF. SOC'Y 
A few years later, in an unpublished manuscript, Rich again explained that patents provide an incentive to invest risk capital for commercialization, which he considered to be "usually the most expensive part of the long haul from the mental conception of the invention to the delivery of something useful into the hands of the consumer."194

Rich also pointed out the importance of patent law's rules for determining what inventions should be patentable. He explained that the legal rules work together with technological facts knowable to all at the time a patent application is filed to make this determination automatic. As he put it,

All the talk about the strength and weakness of patents per se borders on gobbledygook until we learn to comprehend the riddle that: The stronger a patent the weaker it is and the weaker a patent the stronger it is. To explain, a patent that is strong in that it contains broad claims which adequately protect the invention so they are hard to design around is weak in that it may be easier to invalidate and is therefore less likely to stand up in court because the claims are more likely to read on prior art or be broader than the disclosed invention, and for other reasons defense lawyers can devise. On the other hand, the patent with narrow claims of the kind the Patent Office readily allows quickly without a contest is weak as protection and as incentive to invest but strong in that a court will not likely invalidate it. ${ }^{195}$

Indeed, the other major improvement included in the 1952 Act was the introduction of the nonobviousness requirement as an objective test for patentability, in addition to simple novelty, and instead of the more nebulous requirement that to be patentable the invention had to involve "invention."196

Curiously, the TNEC testimony from Commissioner Coe is also quoted in the article that won the prize from the Linthi-

87, 117-18 (1939)).

194. Giles S. Rich, Patents Are Bait 11 (Dec. 1945) (unpublished manuscript on file with author) (citing Judge Frank concurring with an opinion by Judge Hand in Picard v. United Aircraft Corp., 128 F.2d 632, 643-44 (2d Cir. 1942)).

195. Giles S. Rich, The Proposed Patent Legislation: Some Comments, 35 GEO. WASH. L. REV. 641, 644 (1967) (responding to proposed legislation S. 1042 and H.R. 5924, 90th Cong., 1st Sess. (1967) and Report of the President's Commission on the Patent System (1966)). Grady and Alexander have further endeavored to show how courts have applied these rules in decisions that provide incentives to minimize inefficient rent-seeking-and thereby rentdissipating-behavior, thereby more efficiently organizing efforts to invent and commercialize among competitors in markets for such activities over time. See Grady \& Alexander, supra note 66, at 316-21.

196. Not only was the requirement for invention nebulous, it was patently absurd, especially to the uninitiated. Giles S. Rich, Principles of Patentability, 28 GEO. WASH. L. REV. 393, 403 (1960). 
cum Foundation. ${ }^{197}$ In the foreword to the winning article, Dean Wigmore injects what he calls his "personal opinion that neither Courts nor treatise-writers have been radical enough in defending the legitimacy of the 'monopoly' in a patent, as distinguished from the ordinary trade-monopoly," and that he regards it as "unfortunate that courts and treatise-writers have not stood up more boldly for the fundamental right-ness of the patent-right itself." 198

Rich was not the only one to appreciate the importance of patents. Other commentators before the 1952 Act were even able to envision the more modern vision, today often associated with Schumpeter, ${ }^{199}$ that paradoxically, a patent in the hands of a market challenger may evoke competition against a huge industrial monopolist. According to Judge Frank, in this context the David Co. v. Goliath, Inc., competition is dependant upon investment in David Co., which will not occur unless it is armed with the patent slingshot. 200 Rich later asserted this view of patents as potential antimonopoly agents in his commentary on proposed patent legislation. ${ }^{201}$ Today, such a view of patents may help explain why the inability to receive patent protection for software for such a large and important portion of the industry's life may have contributed to the continued unchallenged dominance of a huge entity like Microsoft. ${ }^{202}$

197. LAURENCE I. WOOD, PATENTS AND ANTITRUST LAW 20 (1941).

198. John H. Wigmore, Foreword to LAURENCE I. WoOD, PATENTS AND ANTITRUST LAW vii-viii (1941).

199. See, e.g., SChumpeter, The Theory of EConomic Development, supra note 53, at 61-94; SCHUMPETER, CAPITALISM, SOCIALISM, AND DEMOCRACY, supra note 53, at 81-110; SCHUMPETER, BUSINESS CYCLES, supra note 4 , at 84-192.

200. See Picard v. United Aircraft Corp., 128 F.2d 632, 643-44 (2d Cir. 1942) (Frank, J. concurring).

201. See Rich, supra note 195, at 651 (responding to proposed legislation S. 1042 and H.R. 5924, 90th Cong., 1st Sess. (1967) and Report of the President's Commission on the Patent System (1966)).

202. Early in the rise of the software industry, Judge Rich attempted on several occasions to strike down legal rules against patenting of computer programs. Throughout the 1970 s, he sent numerous cases to the Supreme Court to no avail. See generally CHISUM ET AL., supra note 2, at 763-72, 788-813 (reviewing efforts by Judge Rich to elucidate flaws in the Supreme Court's efforts to block patents on computer software and subsequent appeals to the Supreme Court in those cases, eventually leading to a shift in the Court's views to now allow such protection). Finally, perhaps due in part to a shift in makeup of the Court, he began to have success in Diamond v. Diehr, 450 U.S. 175 (1981), but it was not until In re Alappat, 33 F.3d 1526 (Fed. Cir. 1994) (en banc), and perhaps even State Street Bank \& Trust Co. v. Signature Financial Group Inc., 149 F.3d 1368 (Fed. Cir. 1998), cert. denied, 525 U.S. 1093 (1999), that the 
This controversy over the use of patents to protect subject matter such as living organisms, gene fragments, computer software, and financial services relates to perceived changes in the law governing the threshold patentability requirements of utility and statutory subject matter. ${ }^{203}$ The claimed invention must fall within at least one of the statutory classes of patentable subject matter: products or processes. ${ }^{204}$ Although interpreted expansively to "include anything under the sun that is made by man,"205 these classes do not encompass everything. A common limit on each class is the well-established aphorism that ideas or laws of nature are not patentable subject matter: though Einstein might have been able to patent a method of converting mass into energy, his law $E=m c^{2}$, in and of itself, is not patentable. 206 This takes us back to the utility requirement. ${ }^{207}$ As long as it is claimed in such a way that it performs some useful, concrete, or tangible result, almost any process will at least satisfy the threshold requirements of utility and statutory subject matter. ${ }^{208}$

market fully responded to the availability of patent protection.

203. See supra note 9 .

204. 35 U.S.C. $§ 101$ (1994). Section 101 actually sets forth four specific categories-processes, machines, articles of manufacture, and compositions of matter-but law and practice have long treated the last three together as products.

205. Diamond v. Chakrabarty, 447 U.S. 303, 309 (1980) (citing Committee Reports accompanying the 1952 Patent Act, S. REP. NO. 82-1979, at 5 (1952) and H.R. REP. No. 82-1923, at 6 (1952)); see also In re Bergy, 596 F.2d 952, 961 (C.C.P.A. 1979) (Rich, J.) (citing the same Committee Report for the proposition that patentable subject matter "may include anything under the sun ... made by man" (emphasis added)).

206. See Diehr, 450 U.S. at 185-91. For a detailed review of the requirement for statutory subject matter, see CHISUM ET AL., supra note 2, at 752893.

207. See 35 U.S.C. $§ 101$ (1994). For a detailed review of the utility requirement, see CHISUM ET AL., supra note 2, at 729-51.

208. See State St. Bank \& Trust Co., 149 F.3d 1368, 1375-77 (Fed. Cir. 1998), cert. denied, 525 U.S. 1093 (1999) (holding the hub and spoke mutual fund accounting system to be patent eligible subject matter because the data it manipulates and produces both correspond to and cause something concrete and tangible: a share price, which is money). Although traditional examples of patented inventions include machines and chemicals, it is the more controversial subjects such as genes and gene products, computer software, financial services, and business methods that have spurred on much of the recent criticism facing patent law. Although at one time hotly debated, it is currently settled as a matter of positive law that protection is available in each of these areas. To be sure, the normative debate survives, and indeed thrives. See, e.g., supra text accompanying note 9 . 
What emerges from this review of the writings of those involved in framing our current patent system is that the commercialization theory's link among patents, property rights, and price discrimination clearly operated to inform and motivate their efforts to frame the system. They viewed patents first as incentives to commercialize nascent inventions. ${ }^{209}$ They recognized that patent rights must be set by clear rules of law governing validity and infringement. ${ }^{210}$ And they were deeply motivated by a desire to revive the patentee's ability to use price discrimination by electing to offer either restricted or unrestricted licenses to anyone who would otherwise be subject to suit for direct or indirect infringement. ${ }^{211}$ They also recognized the importance of patents as potential tools for avoiding or challenging monopolies. ${ }^{212}$

209. See supra text accompanying notes 188-198. This particular aspect of the commercialization view, along with use of the word "commercialization," has begun to resurface over the past twenty years in statutes, legislative hearings, and statements by judges. For example, the Bayh-Dole Act, passed in 1980, Pub. L. No. 96-517, 94 Stat. 3015, 3018-28, § 6(a) (1980) (codified as amended at 35 U.S.C. $\S \S 200-212$ (1994)), encourages universities to seek and retain patent rights on the results of federally funded research for the express purpose of using "the patent system to promote the utilization of inventions arising from federally supported research or development ... [and] to promote the commercialization and public availability of inventions made in the United States.” 35 U.S.C. $\$ 200$ (1994) (stating the purposes of the act). Similarly, in hearings leading up to the Bayh-Dole Act, Harry F. Manbeck, who subsequently became Commissioner of the Patent and Trademark Office, argued that "[u]nless the universities get substantial rights from patents, there is absolutely no incentive for them to establish technology transfer and patent programs which may lead to commercialization of the research." Patent Policy: Hearings on S.1215 Before the Subcomm. on Science, Technology, and Space of the Senate Comm. on Commerce, Science, and Transportation, 96th Cong. 302 (1979) (statement of H.F. Manbeck, Jr., General Patent Counsel, General Electric Co.). See also In re Alappat, 33 F.3d 1526, 1571 (Fed. Cir. 1994) (Newman, J., concurring) ("What seems to be missing in our country is an understanding that, no matter how much money we spend on research and development, the findings are not going to benefit the public unless there are suitable incentives to invest in commercialization. That means a chance of reasonable profits from risk taking and a chance to hold onto one's original ideas once they are created" (quoting approvingly Irving S. Shapiro, Address Before the Economic Club of Detroit (1979), in XLV VITAL SPEECHES OF THE DAY 360, 364 (1979))); Foreword, in CHISUM ET AL., supra note 2, at iii (consisting of statement by Judge Giles S. Rich that probably the most important function of the patent system is "to encourage the investment of risk capital in the commercialization of inventions so that the public gets to enjoy the benefits thereof").

210. See supra text accompanying notes 178-87, 195-96.

211. See supra text accompanying notes 165-67, 178-83.

212. See supra text accompanying notes 199-202. 


\section{COMMERCIALIZATION AND THE MODERN PATENT SYSTEM}

The commercialization view of patents helps explain many controversial trends in the current patent system, including those that sparked the recent critical commentary. ${ }^{213}$ Under this view, the increases in predictability in patent litigation and certainty in patent law that have been attributed to the creation of the Federal Circuit and areas of that court's case law are good things. ${ }^{214}$ They have helped forge clearly marked and enforceable property rules for patents. ${ }^{215}$ Similarly, under this view, it is also good that patents are now being used to protect subject matter such as living organisms, gene fragments, computer software, and financial services, which many previously considered to be ineligible for patent protection. ${ }^{216}$ This makes sense because some form of protection is necessary to permit recovery of commercialization costs in markets such as these, ${ }^{217}$ precisely because they are characterized by a particularly large difference between average cost and marginal cost. ${ }^{218}$ Indeed, the need for protection is especially strong in markets such as these because commercialization costs represent a significant component of average cost. 219

Consider, for example, the topic of patents on financial services. A recent article by Van Zandt suggests that there is suboptimal innovation in capital markets. ${ }^{220}$ Van Zandt suggests that at least one of the reasons for suboptimal innovation

213. See supra text accompanying notes 8-12.

214. See supra text accompanying note 8 .

215. See discussion supra Part II.

216. See supra text accompanying notes 9, 203-08.

217. See discussion supra Parts I.A, II.A.

218. Contra SHAVELL \& VAN YPERSELE, supra note 10, at 11 (arguing that the large difference between average cost and marginal cost for these technologies makes use of patents particularly harmful); KREMER, supra note 11, at 7 (same). The need for patent protection is strong because first movers in such markets face high costs of commercialization, whereas second movers face only low costs of making and selling. See discussion supra Part I.A.

219. In this regard, the commercialization view of patents considers the growth and survival of a single player with large market power in the software industry - like Microsoft — one of only a few evolutionarily expected outcomes. Monopoly power provided a method for allowing the firm to recover average costs in the absence of patent protection. See supra text accompanying note 202.

220. See David Van Zandt, The Organization of Innovation in International Capital Markets 7-14 (Mar. 22, 1995) (unpublished manuscript, on file with author). 
in this market is the high cost of creating a market combined with the ease of competitive copying. ${ }^{221}$ He explains that only the largest few players in the industry regularly bring new products to market. ${ }^{222}$ It is not surprising, then, that the commercialization view of patents may provide an easy solution. In the language of Demsetz, the threat of copying prevents the small firms from being able to concentrate the benefits of commercialization. ${ }^{223}$ They therefore elect not to invest in commercialization at all. Only the larger players can afford to invest the resources to bring such products to market. According to the commercialization theory, the availability of patent protection may enable small firms to enter the market, and perhaps even challenge their larger counterparts. 224

The commercialization view of patents may also help explain outcomes on recent legislative activity in the patent arena. For example, efforts to harmonize the U.S. patent system with those of the rest of the world frequently receive substantial attention from Congress and commentators. ${ }^{225}$ Typical legislative proposals have included the following: shifting patent term so it is measured as twenty years from earliest filing date rather than seventeen years from issue date, ${ }^{226}$ allowing the filing of provisional patent applications, which would establish a priority date for a low fee but would have to be converted to a regular application by the applicant in order to be examined; ${ }^{227}$ the publication of patent applications eighteen months after filing; ${ }^{228}$ and moving from a first-to-invent system to a first-to-file system. ${ }^{229}$

Those suggested changes that have already been made are in accord with the commercialization view. Twenty-year-term

221. See id. at 7-11.

222. See id. at 15-19.

223. See discussion supra Part II.A.

224. See supra text accompanying notes 199-202.

225. See, e.g., Patent Harmonization Act of 1992, S. 2605, 102d Cong. (1992), H.R. 4978, 102d Cong. (1992) [hereinafter Patent Harmonization Act of 1992]; Edward G. Fiorito, The "Basic Proposal" for Harmonization of U.S. and World-Wide Patent Laws Submitted by WIPO, 73 J. PAT. \& TRADEMARK OFF. SoC'Y. 83 (1991) (summarizing harmonization efforts of the World Intellectual Property Organization (WIPO), a specialized agency of the United Nations).

226. See Patent Harmonization Act of $1992 \S 6$.

227. See id. $\S 4$.

228. See id.

229. See id. $\S 3$. 
and provisional applications were passed into law in 1994.230 Eighteen-month-publication was passed into law in 1999.231 Under the commercialization view, the shift in patent term can be seen as an aid in clearing the patent register.232 Similarly, eighteen-month-publication can be seen as an important signaling tool for controlling the potential rent-seeking, and therefore rent-dissipating, behavior of those who would be lured into doing inventive effort by the potential profits from a patent. 233

In contrast, the shift from a first-to-invent system to a first-to-file system has not yet been implemented and may not be in accord with the commercialization view. In the existing U.S. patent system, when two or more patent applications or patents claim the same invention, or an application is filed claiming the same invention as a recently issued patent, the Patent and Trademark Office will commence an interference proceeding to determine priority of invention. ${ }^{234}$ Under a firstto-file system, priority is awarded to the application that is filed first, regardless of priority of invention. ${ }^{235}$ Much of the

230. See supra note 164 (citing Pub L. No. 103-465, 108 Stat. 4809 (1994)); see also 35 U.S.C. $\$ 154$ (term); 35 U.S.C. $\$ 111$ (b) (provisional applications).

231. See Pub L. No. 106-113, 113 Stat. 1501 (1999).

232. See also supra text accompanying notes 159-60. In addition, Congress has established an inter partes reexamination procedure with participation by third parties (other than the Patent Office and the patentee) for administrative adjudication of the validity of issued patents by the Patent Office as a less costly alternative to proceeding in Federal Court. Pub. L. No. 106-113, 113 Stat. 1501A-567-71 (1999). This new reexamination procedure may enhance the policing role played by competitors of the patentee. See discussion supra Part I.B.

233. See, e.g., Grady \& Alexander, supra note 66, at 314-16 (discussing the principals of "signaling," which leads to races for patents and rent dissipation); see also supra text accompanying notes 66-67 (noting concern about potential rent-seeking behavior at the pre-invention stage).

234. See 37 C.F.R. § 1.601 (1999); 35 U.S.C. $§ 102(\mathrm{~g})$ (1994). The second party to file (the junior party) has the burden of proving prior invention by a preponderance of the evidence. Priority of invention is determined pursuant to the requirements of 35 U.S.C. $\S 102$. The first party to conceive of the invention will win the interference if she is also the first to reduce the invention to practice. If she is not the first to reduce to practice, she will win the interference only if she can prove diligence in her efforts to reduce the invention to practice. Reduction to practice may be either actual or constructive, through the filing of a patent application. See MANUAL OF PATENT EXAMINING PROCEDURE $§ 715.07$ (7th ed. 1998). The interference practice resulting from $\S$ $102(\mathrm{~g})$ is the basis for the so-called "first-to-invent" aspect of the United States patent system. For more on the priority of invention and interferences, see CHISUM ET AL., supra note 2, at 485-529.

235. See Patent Harmonization Act of $1992 \S 3$. 
debate $^{236}$ over first-to-file versus first-to-invent can be seen in context of the general debate over rules versus standards, fairness versus certainty, and efficiency. ${ }^{237}$ The incentive to commercialize theory may, however, provide special insight for resolving the particular debate applied to patents. While one contestant may emerge holding the property right from a priority dispute under a first-to-invent system, a first-to-file system may be more likely to yield no property right at all. ${ }^{238}$ The increased incentive to file early under a first-to-file system, as compared with a first-to-invent system, may lead to an increase in the number of patents being held invalid for inadequate disclosure in their underlying applications, thereby diminishing incentives to engage in commercialization activities. ${ }^{239}$ The incentive to commercialize view thus helps explain the persistence of the existing first-to-invent regime.

236. See generally Patent Harmonization Act of 1992: Joint Hearing Before the Subcomm. on Patents, Copyrights and Trademarks of the Senate Comm. on the Judiciary and the Subcomm. on Intellectual Property and Judicial Admin. of the House Comm. on the Judiciary on S. 2605 and H.R. 4978, 102d Cong. (1992) (collecting testimony and sources on both sides of the debate).

237. See generally MARK KELMAN, A GUIDE TO CRITICAL LEGAL STUdiES 15-64 (1987) (discussing the rules versus standards debate in the context of general legal systems and arenas).

238. To be sure, patentability or validity issues can be raised in priority disputes under both systems; the operative distinction here is that first-to-file systems may give rise to increased validity problems.

239. A hastily filed application is more likely to be found invalid for nonenablement or lack of written description under recent Federal Circuit case law. See Amgen Inc. v. Chugai Pharm. Co. 927 F.2d 1200, 1213-18 (Fed. Cir. 1991) (applying the statutory requirement that the text of the patent application as filed contain sufficient disclosure to enable one in the art to make and use whatever is covered by patent claims as eventually issued and applying separate written description requirement to claims in the field of biotechnology); Vas-Cath Inc. v. Mahurkur, 935 F.2d 1555, 1563-67 (Fed. Cir. 1991) (holding that the statute also requires the text of the patent application as filed to satisfy the separate and distinct written description requirement so as to reasonably convey to those in the art exactly what is covered by the patent claims as eventually issued); Amgen v. Chugai, 927 F.2d 1200, 1213-18 (applying separate written description requirement to claims in the field of biotechnology); Fiers v. Revel, 984 F.2d 1164, 1170-71 (Fed. Cir. 1993) (solidifying the court's position on a separate written description requirement); Regents of the Univ. of Cal. v. Eli Lilly \& Co., 119 F.3d 1559, 1566-69 (Fed. Cir. 1997) (further solidifying the court's position on a separate written description requirement); Lockwood v. Am. Airlines, Inc., 107 F.3d 1565, 1572 (Fed. Cir. 1997) (applying the same written description requirement to the field of computer software); Gentry Gallery, Inc. v. Berkline Corp., 134 F.3d 1437, 1479-80 (Fed. Cir. 1998) (indicating that the written description requirement is not limited to complex technologies but applies equally to simple technologies, like sofa recliners); see also supra text accompanying notes $115,170$. 


\section{COMMERCIALIZATION AND THE MODERN TRADEMARK SYSTEM}

The commercialization theory of patent law may also help explain controversial aspects of trademark law. Consider, for example, a trademark that has become so well known, consumers now view it as a distinct good or service. Consider that some consumers may even like it so much that they use it as decoration. It cannot be that every customer who buys a Mickey Mouse shirt supposes that the quality of the shirt owes anything to Walt Disney Productions. Even if the consumers think there is some licensing arrangement between the shirt seller and Disney, that arrangement may be irrelevant to the decision to buy.

To make the case stronger, consider the argument by Kozinski about T-shirts bearing a New York Mets logo, in which he urges that a fan has a strong claim to express team admiration, and an even stronger claim to express team criticism. ${ }^{240}$ From there, he adds, it is only a small step to say that the fan ought to be able to pay someone to stencil the shirt professionally. ${ }^{241}$

In a recent tribute symposium to the late Ralph Brown, Lemley and Litman argued that any trend in trademark law that permits the propertization of trademarks - such as the merchandizing right in the sports context-is simply an improper use of the law of trademarks. ${ }^{242}$ For them, the touchstones and the limits of trademark theory are designations of source and confusion. ${ }^{243}$ Lemley asserts that "it does not follow

240. See Alex Kozinski, Trademarks Unplugged, 68 N.Y.U. L. REV. 960, 976 (1993). For example, team admiration might be expressed by the wearing of a T-shirt bearing just the logo, or the logo preceded by the slogan "up with." Team criticism might be expressed by wearing a T-shirt bearing a defaced logo, or a logo preceded by the slogan "down with," or some inelegant version thereof.

241. Id.

242. See Mark A. Lemley, The Modern Lanham Act and the Death of Common Sense, 108 YALE L.J. 1687, 1705-09 (1999); Jessica Litman, Breakfast with Batman: The Public Interest in the Advertising Age, 108 YALE L.J. 1687, 1717, 1728-31 (1999).

243. See Lemley, supra note 242, at 1705-09. Lemley intimates reasoning similar to Kozinski, supra note 240: a fan or critic who is merely interested in speaking about the Mets cannot be confused about source because source is irrelevant to the decision to buy the shirt. The purpose of buying the shirt for such an owner is to speak about the team. Indeed, the presence of a licensing arrangement behind the shirt sale might undermine the rhetoric of, or even offend, the speaker if the message of the speech is critical of the team. 
that because something is valuable it must be owned."244 Further, in an article that bears the running title "Breakfast with Batman," Litman urges, "An argument that we would have an undersupply of good commercials ... cannot be made with a straight face." 245

At least the beginnings of the counterargument are found in the trademark dispute over Batman himself in the 1982 DC Comics case. ${ }^{246}$ There, Judges Rich and Nies began by pointing out that there is not, and should not be, any principle of trademark law that requires imposition of a penalty for the originality, creativeness, attractiveness, uniqueness, or even fame of one's product, or that requires a holding that the unique design or other features of a product cannot also function as a designation of source. ${ }^{247}$ They note that the opposite rule

has led some courts into an esoteric and extraneous inquiry focusing on what motivates the purchasing public to buy particular goods, the product itself or the source.... The reason the public is motivated to buy the product ... is of concern to market researchers but is legally immaterial to the issue of whether a particular designation is generic. ${ }^{248}$

They do recognize the safeguard that trademark "[p]rotectibility is lost when the public uses what was a proper name [the mark] to denominate like or similar goods from other sources as well." ${ }^{49}$ Yet they conclude that "it would be unfortunate were we to discourage use of a spark of originality which would transform an ordinary product into one of grace." 250

Restructuring the discussion into the framework of Demsetz, the question is not whether we will see a decrease in commercials - although fans of Superbowl commercials may feel otherwise - but, rather, whether we will see a decrease in the development of highly popular marks. Underlying the reasoning of Judges Rich and Nies is a recognition that trademark rights in such marks encourage firms to invest in promoting new highly entertaining marks in an effort to make them popular. As Landes and Posner noted, if appropriation is forbidden by a property rule, the benefits of such popularization will be

244. Lemley, supra note 242 , at 1709.

245. Litman, supra note 242 , at 1730 .

246. See In re DC Comics, Inc., 689 F.2d 1042, 1046-55 (Fed. Cir. 1982) (opinions of Judge Rich and Judge Nies concurring separately in result).

247. Id. at 1053.

248. Id. at 1054 .

249. Id.

250. Id. at 1050 . 
internalized to mark owners and the amount of investing in potentially famous marks will rise. ${ }^{251}$ Although this may seem frivolous to some, the audience who makes it happen must feel otherwise. After all, they will have devoted the attention necessary to make the mark so valuable. Indeed, this may cause some in the audience to argue that it is precisely because of this investment on their part that ownership, if there is any, lies entirely with them. ${ }^{252}$ It would run afoul of basic principles of capitalism, however, to suggest that the requirement to pay for a good should evaporate simply because a consumer has developed a particularly strong interest in the good-particularly if it is a luxury good.

\section{CONCLUSION}

This Article offers a new view of the patent system in which a central goal is to facilitate commercialization of new goods and services. Under this view, treatment of patents as property rights provides incentives for the investment and ordering of private activities necessary for such a complex commercialization process while at the same time providing a workable framework for deciding which inventive activities merit government intervention in the first instance. According to this view, patents can promote commercialization without creating dead-weight loss through the use of price discrimination and strict and clearly marked property rules. In this regard, this Article provides a moral realist or natural law view of the patent system as a legal regime getting it right.

This Article also demonstrates how the link among patents, property rights, and commercialization informed the creation of our current patent system. The offered view of the system may help explain many controversial trends, including those that sparked recent critical commentary, as well as those in other areas of intellectual property law, such as trademarks. This Article therefore simultaneously provides support for the present patent system under three additional philosophical views. Under an intentionalist view, the system we have today is in keeping with the intent of those who framed it. Under a positivist view, the system we have today is in keeping with the system as created. Under a legal realist view, the system we

251. See William M. Landes \& Richard A. Posner, The Economics of Trademark Law, 78 TRADEMARK REP. 267, 304 (1988).

252. See Litman, supra note 242 , at 1730 . 
[Vol. 85:697

have today is in keeping with the goals of the winning side in the contest surrounding its creation.

The commercialization theory offered in this Article shows how disparate features of the existing patent system-previously thought to be unrelated or mutually antithetical-actually operate together to effectively promote invention commercialization. While endeavoring to answer Dean Wigmore's request for someone to stand up more boldly for the rightness of the patent system, ${ }^{253}$ this Article has also provided a new and useful framework for studying the operation of the system and for testing proposed changes or alternatives.

253. See Wigmore, supra note 198. 